\title{
An Epipalaeolithic hunting camp in the west of France. Site 1 of the Auvours Camp in Saint-Mars- la-Brière (Sarthe, France)
}

Un campement épipaléolithique de chasseurs dans l'ouest de la France. Le site 1 du Camp d'Auvours à Saint-Mars-la-Brière (Sarthe, France)

\section{Michel Allard}

\section{OpenEdition}

\section{Journals}

\section{Electronic version}

URL: http://journals.openedition.org/paleo/2855

DOI: 10.4000/paleo.2855

ISSN: 2101-0420

\section{Publisher}

SAMRA

\section{Printed version}

Date of publication: 15 December 2013

Number of pages: $21-46$

ISSN: $1145-3370$

\section{Electronic reference}

Michel Allard, «An Epipalaeolithic hunting camp in the west of France. Site 1 of the Auvours Camp in Saint-Mars-la-Brière (Sarthe, France) », PALEO [Online], 24 | 2013, Online since 03 September 2015, connection on 07 July 2020. URL : http://journals.openedition.org/paleo/2855 ; DOI : https://doi.org/ 10.4000/paleo.2855

This text was automatically generated on 7 July 2020 . 


\title{
An Epipalaeolithic hunting camp in the west of France. Site 1 of the Auvours Camp in Saint-Mars-la- Brière (Sarthe, France)
}

\author{
Un campement épipaléolithique de chasseurs dans l'ouest de la France. Le site 1 \\ du Camp d'Auvours à Saint-Mars-la-Brière (Sarthe, France)
}

Michel Allard

1 From 1970 to 1979 , we directed excavations at site $\mathrm{n}^{\circ} 1$ at the open-air prehistoric site of Auvours Camp, at Saint-Mars-la-Brière (Sarthe). From 1983 onwards, the reorganization of the Pays de la Loire DRAC and the Midi- Pyrénées DRAC put an end to the excavation and took us away from our research.

In 1993, the excavation was accidentally destroyed by army personnel during the construction of a track along the site.

It appears essential to us to transmit what we learned from site 1 of Auvours, not only in terms of the abundant lithic material curated at the Musée du Mans, but also in terms of the observations carried out on site. Although these investigations were not brought to completion, as we had wished, they nonetheless provide evidence of the study conditions, observations and methods implemented to optimize the partial results. The present paper thus presents a summary of our work on the site.

4 It is true that archaeological research has made huge progress since the 1970s, particularly in the fields of rescue archaeology and computing. However, although the study of archaeological finds can be reviewed on a permanent basis, field observations can only be conducted during excavations. In this case, the destruction of site 1 of Auvours rules out the possibility of validating fieldwork. It is for this reason that we wish to share most of what we learned in this paper.

5 Up until now, we published two preliminary publications on site 1 of Auvours (Allard 1982) (Allard and Guyot 1972). However, in the Gallia-Préhistoire review, J. L'Helgouach 
$(1971,1973,1975,1977,1979)$ published several sections on the site, written by us at his request.

\section{1 - Environmental context}

\section{1 - Localization}

The military camp of Auvours is located about fifteen kilometres east of Mans, north of the road of Blois near the intersection with the R.N.23 (fig. 1-a). It is situated on a trapezoidal-shaped territory, about $400 \mathrm{~m}$ wide in the west, widens regularly towards the east over $8 \mathrm{~km}$ until the Butte d'Ardenay, where it attains a width of 1,400 $\mathrm{m}$

7 The military administration is confined to the western extremity of this expanse and the rest is used as a vast shooting ground. At about two-thirds of its length, the Narais stream crosses the camp. The area concerned by our study is located on the right bank of this stream near Saint-Etienne-du-Narais, at the internal limit of the camp separated from the Blois road by a privately-owned wooded heath, about sixty metres wide.

Figure1a - Geographic location of the prehistoric site of the camp of Auvours according to the map of Bouloire 1/50 000. Figure 1b - Cadastral location of sites 1-5.
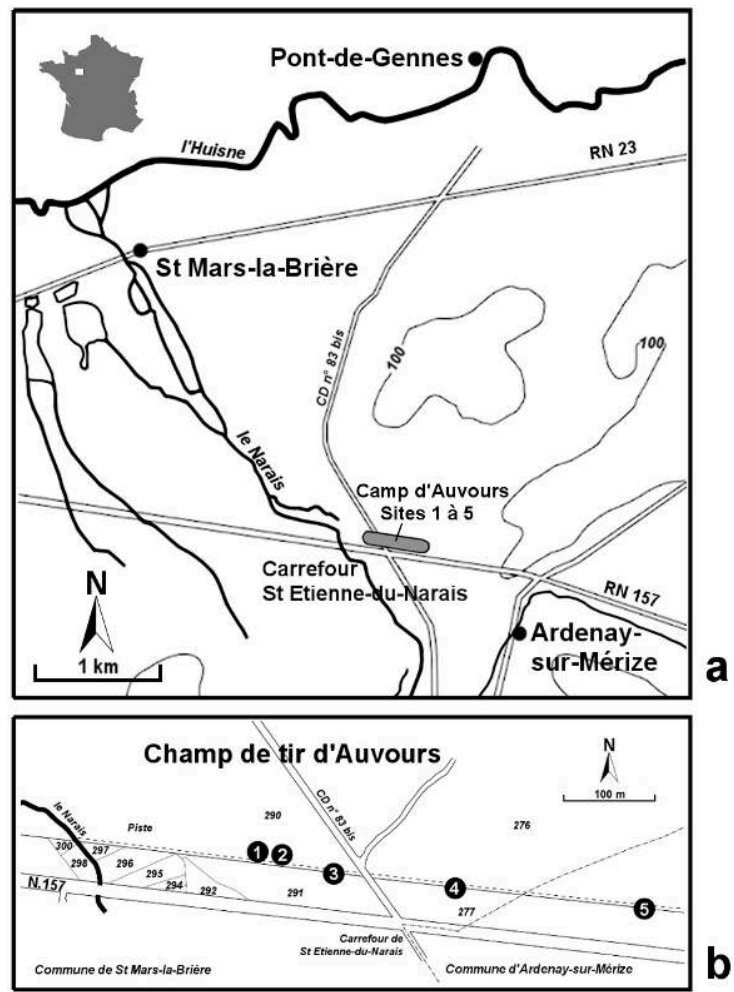

\section{2 - History}

The prehistoric site of Camp d'Auvours was discovered in 1969 by R. Guyot, correspondent for Antiquités Préhistoriques, during prospecting carried out at the southern limit of the shooting range between the Narais stream and the Ardenay mound (fig. 1b, photo 1). In this zone, along the track on the edge of the camp, a strip of land about fifteen metres wide had been stripped of topsoil. The topsoil was pushed 
towards the other side, forming a continuous mound, 1 to $2 \mathrm{~m}$ high. The exposed sandy ground was intended as a firewall in the event of the outbreak of fire. After the discovery of abundant knapped flint pieces on the sand, R. Guyot carried out systematic surface prospecting. He noticed five concentrations of flint over a distance of about 600 $\mathrm{m}$. The gathered lithic material was made up of end scrapers, burins and abundant backed bladelets and was identified as being probably Magdalenian.

After having notified the Direction des Antiquités Préhistoriques, and in agreement with R. Guyot, we conducted several surveys on the site. These surveys enabled us to gather abundant lithic material from the firewall and the humus in the lateral talus, and to localize the sites. Four of these sites are on the territory of Saint-Mars-la-Brière and the fifth is on the townland of Ardenay-sur-Mérize. They have been numbered 1 to 5 from the west to the east. The first three sites located west of the departmental road $\mathrm{n}^{\circ} 83$ bis seem to be part of the same culture. On the other hand, sites 4 and 5 contain less material and are less extensive. They appear to correspond to other cultural levels and are difficult to identify. These sites are only slightly buried as they were exposed after a simple stripping of the topsoil. Sites 3,4 and 5 also yielded material in the ditches beside the track cutting through them. North of the firewall, in the Ericacea heath dotted with birch trees, isolated discoveries of lithic objects tend to illustrate the presence of other sites in the shooting ground.

Photo 1 - Aerial view of site 1 (photo J. Rioufreyt, 1972)

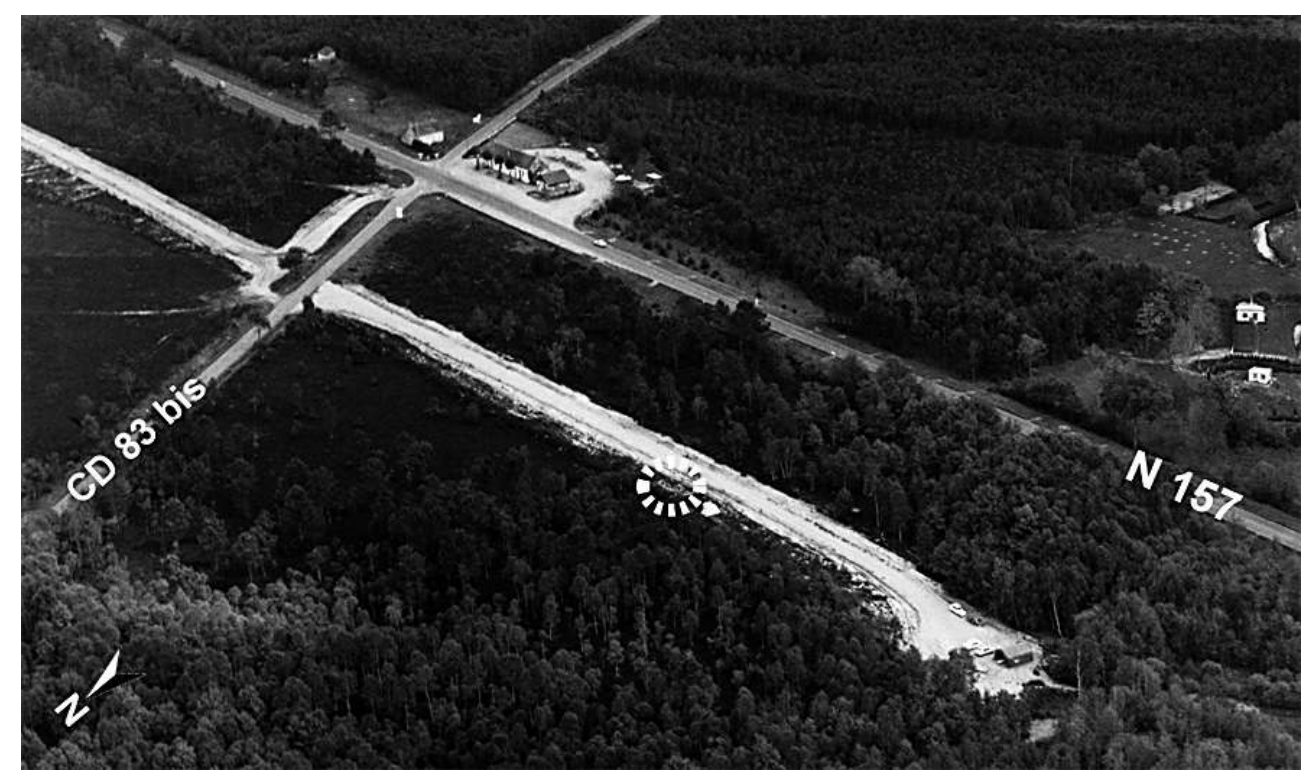


Figure 2 - Geological location of site 1, according to the geological map of Bouloire 1/50,000.

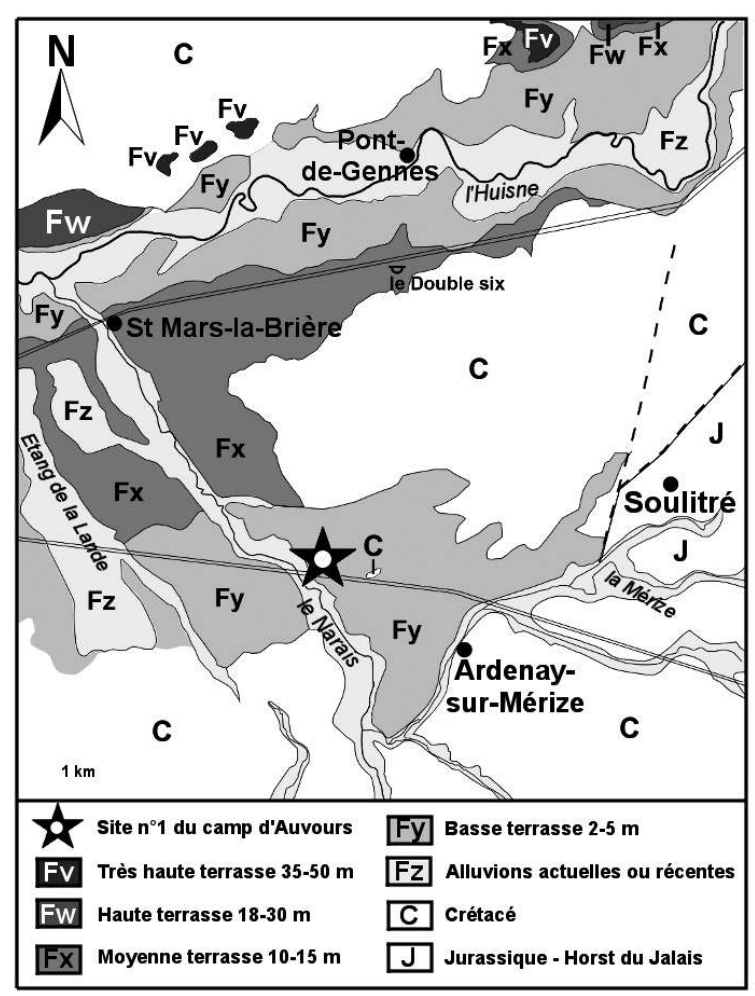

\section{$1.3-$ Geological context}

10 According to the geological map (Bouloire 1/50 000) (fig. 2) and studies carried out by Guy Mary (Mary 1964), a geologist at the Maine University specialized in the region of Mans, with whom we discussed the excavation of site 1, the site surroundings are made up of ancient alluviums deposited at varied altitudes in relation to the main Narais channel, surrounded by marshland near the Huisne confluence. These alluviums are laid out in inset terraces but have been partly dismantled by erosion, and only the most recent levels have been preserved (low terrace of 2-5 $\mathrm{m}$ and the middle terrace of 8-15 $\mathrm{m})$.On the other hand, on the right bank of the Huisne, several remnants of the high $(18-30 \mathrm{~m})$ and very high $(35-50 \mathrm{~m})$ terraces subsist. The walls of the high stepped terraces which marked out the left bank of the Huisne at the beginning of the Quaternary have thus been progressively destroyed by erosion. Therefore, at the Auvours Camp, the present relief was undoubtedly quite close to the Tardiglacial landscape when the prehistoric sites were implanted on the low terrace on the right bank of the Narais, and for site 5, on the slope of a small remnant Cenomanian mound.

11 The low Auvours terrace is made up of sands and gravels mixed with some debris from Jurassic limestone outcropping six kilometres to the east in the Jalais horst. The leaflet of the 1/50,000 geological map of Bouloire (Obert 1988 - p. 24) indicates that the terrace "contains blocks of sandstone carried by ice pans (Saint-Mars-la-Brière)". At the site 1 location, blocks transported in this way make up a natural pavement. According to the map, this formation, in which "remains of Mousterian industry were found, would be of Wurmian age". For the time being, we are not aware of the extent of this pavement, which is only present in site 1 of the studied zone. The excavation showed that when 
the prehistoric groups set up camp here, the pavement was already affected by gelifraction and strong corrosion during the Upper Palaeolithic. After the site was abandoned, it was covered by a sandy layer made up of elements transported by runoff and the wind, as confirmed recently by the geologist G. Mary in 2013.

It is unfortunate that we could not devote more time to localizing the origin of the grey flint used by the prehistoric groups of the Auvours Camp. The only blocks observed were located in the clayey terrains beside the site, near Saint-Denis-du-Tertre, 1,500 m towards the north, but these appear to be too small to have been used. On the other hand, the grindstone used at the site could easily have been taken from the nearby site environment, particularly south of the Loudon wood where military personnel from the camp showed us large residual blocks.

Given these geological data and the fact that we did not discover any workable raw materials on site 1 , we cannot validate the hypothesis advanced by N. Naudinot (Naudinot 2008 - p. 259) concerning the introduction of workable lithic raw materials by solifluction.

\section{4 - The prehistoric environment: The other sites discovered}

\subsection{1 - Site 2}

14 Site 2 was located between $140 \mathrm{~m}$ and $145 \mathrm{~m}$ west of the $800 \mathrm{~m}$ milestone of the CD 83 bis, in the firewall. This site was also destroyed and appeared to correspond to the same culture as site 1 . However, no paving remains were identified here. Surface prospecting yielded 216 flint pieces, including two cores, two proximal backed points and 16 plates with red ochre. It may have been a smaller or more deeply buried site than site 1 .

\subsection{2 - Site 3}

The military track cut into this site at a distance of 60 to $70 \mathrm{~m}$ west of the $800 \mathrm{~m}$ milestone. In 1979, the cleaning of the ditches running along the track resulted in a rescue operation which brought to light a prehistoric installation with a thick combustion level. 847 flint pieces were collected from this site, including five cores and a single ochre-stained plate.

16 The tools include nine end scrapers, four burins, nine armatures and three truncated blades. The lithic finds from site 3 are similar to those from site 1, but no blocks are present here.

\subsection{3 - Site 4}

17 This site is a human installation intersected by the military track between $120 \mathrm{~m}$ and $140 \mathrm{~m}$ east of the previously cited $800 \mathrm{~m}$ milestone. The finds from this site are made up of 83 flint pieces, including 9 bladelike pieces and 20 bladelets, a burin on a break and a backed point.

\subsection{4 - Site 5}

18 This rather spread out human implantation was located on the upper part of the slope of a small hill, between $400 \mathrm{~m}$ and $450 \mathrm{~m}$ east of the $800 \mathrm{~m}$ milestone. It yielded 265 flakes and debris, 35 non-retouched bladelets, 53 non-retouched blades and five blade 
cores. The toolkit includes about ten pieces including a small fan-shaped end scraper, a borer, a burin on a fracture, two armatures and a scalene triangle. The site also contained a flint nodule with a large open geode and a sort of handle (photo 2), somewhat reminiscent of the two parts of the burner from Lascaux (Glory 1961). This partially heat-cracked and reddened nodule bears very clear traces of burning on the edge of the geode, which could correspond to the location of a wick. The characteristic marks suggest that it was chosen for its natural shape by prehistoric groups, with a view to being used as an oil lamp.

Photo 2 - Site 5. Flint nodule with geode (photo M. Allard).

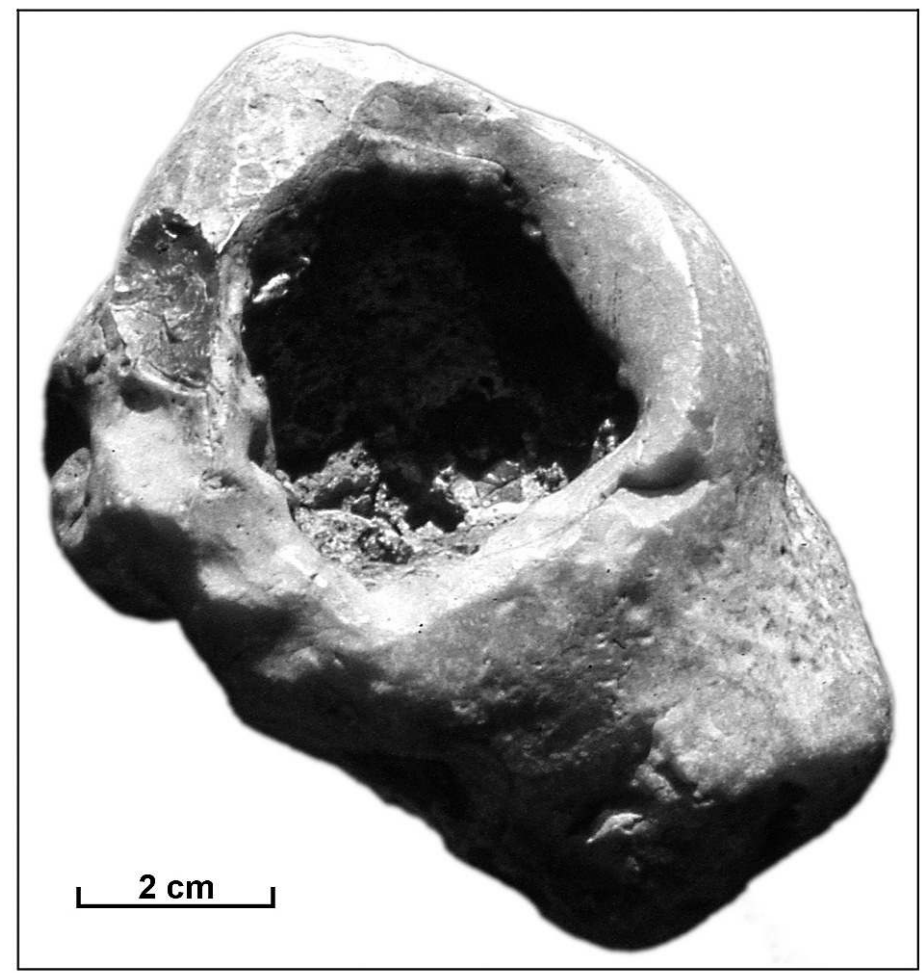

\section{2 - Investigation techniques applied to site 1 and research issues}

\section{1 - Preliminary work: Sifting and test pits}

\subsection{1 - Sifting}

The first work on site 1, which contained more archaeological material in the firewall than the other sites, began in 1970 (fig. 3).

As initially we assumed that the terrain had been reworked, we carried out sifting over a surface of 4 square metres. It very soon became clear that the podzol containing the archaeological layer was intact from 2 to $3 \mathrm{~cm}$ below the surface. From then on, we ceased sifting in this sector and began to sift the spoil making up the nearby talus. As the latter had a high humus content, we had to use a soaking and sifting system in order to extract the prehistoric pieces. This operation was facilitated by the use of a 
water cistern provided by the military camp, which resulted in the recovery of 2,600 flint pieces, including 77 tools. This enabled us to attribute the site to the terminal Palaeolithic.

\subsection{2 - Test pits} in the intact heath, $20 \mathrm{~m}$ north of the axis of the track.

Figure 3 - Location of worked zones.

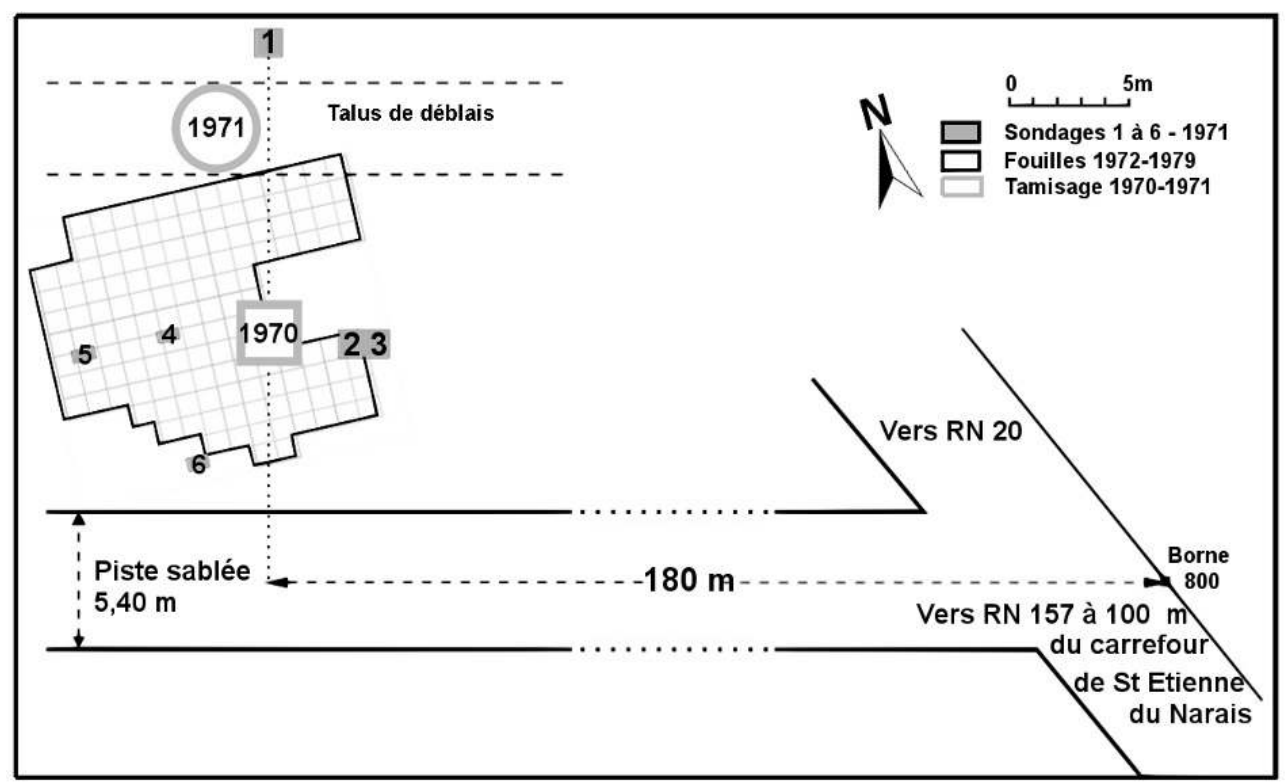

The abundant lithic material (385 flints) indicated that it was probably part of site 1 . The stratigraphy of this testpit, based on contemporaneous pedology work by G. Aubert. and J. Boulaine (1967), and more recently on analyses by P. Duchaufour (2001) and D. Baize (2000 and 2005), yielded the following results:

- 0-2 cm: brown-black crude humus with several identifiable plant debris (horizon OF).

-2-20 cm: dark brown fine sandy layer with a high organic matter content (coarse humus), containing several sandstone elements with a whitened surface (horizon $\mathrm{OH}$ ).

- 20-25 cm: brownish sand becoming paler towards the base (horizon A).

-25-45 cm: pale grey well-developed layer, sandy-silty and stony, mostly quartzous. This is horizon $\mathrm{E}$ with an ash podzol structure.

- 45-55 cm: very compact organic black, silty-stony layer. It characterizes horizon BPh (spodic horizon).

The other test pits conducted in the firewall all yielded comparable stratifications, except that they were superficially truncated by the stripping of the vegetal layer. 

angle of the S5 test pit (square 7-B), the top of which was painted red and corresponds to $-45 \mathrm{~cm}$. The vertical coordinates relative to this point were recorded using water levels spread out over the surface of the excavated squares (141 square metres). However, in order to facilitate the reading of the present publication, the grid reference points used on site have been transposed here into a more simple system in which the metric units are represented by letters on the abscissa axis and by numbers of the ordinate axis. The excavation was conducted under shelter on a mobile board (photo 3). 
Photo 3 - Aspect of the excavation in 1977 (photo M. Allard).

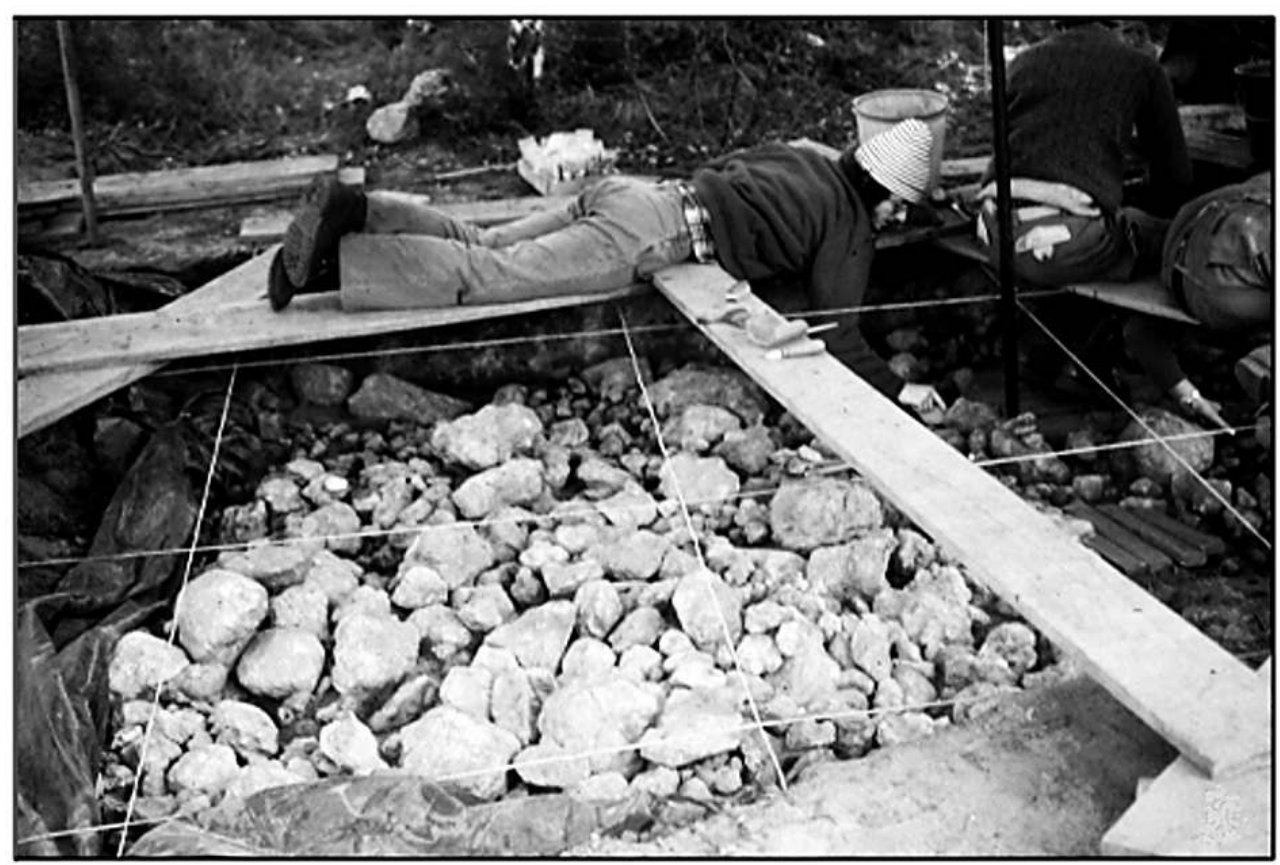

\subsection{1 - Technique applied to the lithic material}

During the first years of the excavation, the lithic material was individually numbered and recorded using the three axes XYZ. The diagram of vertical distribution (fig. 4) locates the archaeological level between $40 \mathrm{~cm}$ and $50 \mathrm{~cm}$ from the general zero except in squares $7 \mathrm{G}$ and $7 \mathrm{H}$ (hearth F1) where it is a little deeper. The vertical dispersion of the archaeological material would be attributable to burrowing animals and roots. The dry sifting of the sediments from each square using a $1.7 \mathrm{~mm}$ mesh, followed by the soaking of these sifting remains in a basin, facilitated the recovery of the lithics. 
Figure 4 - Distribution graph of the archaeological finds according to depth in squares 7-E, 7-F, 7-G, 7-H, 7I.

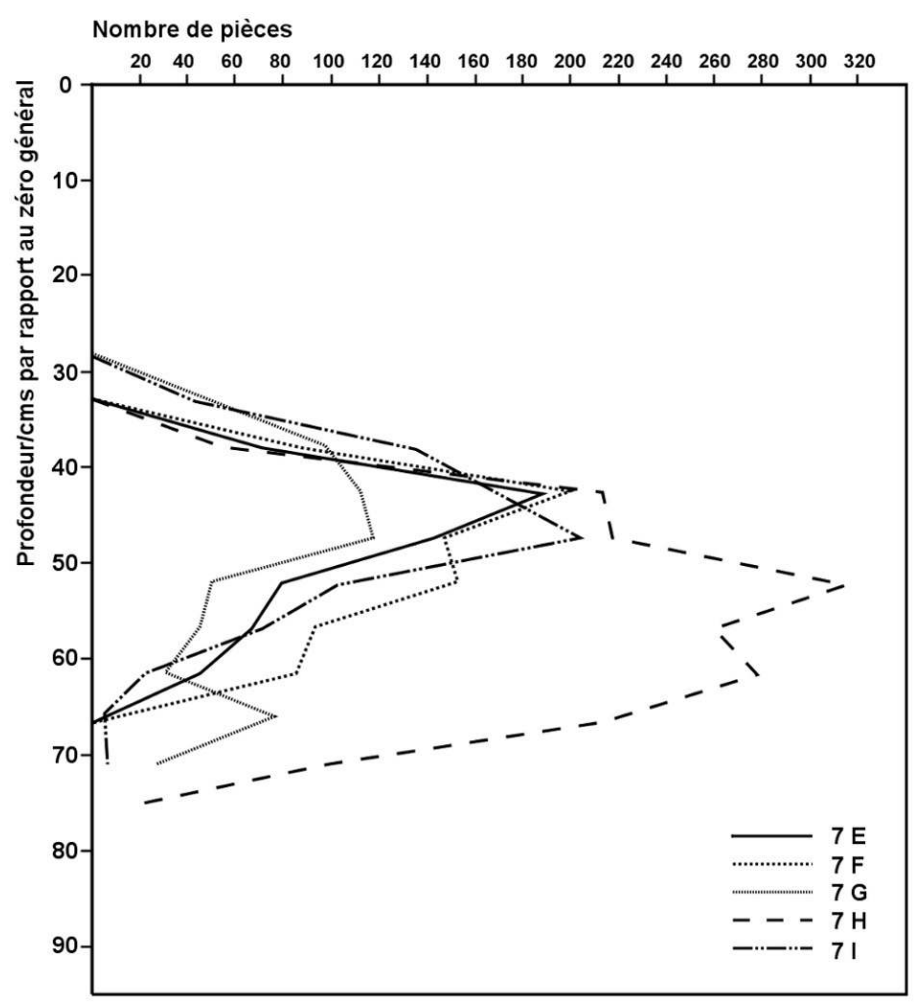

\subsection{2 - Technique applied to the sandstone blocks}

The vertical photography of each square enabled us to establish a photomontage of all the exposed sandstone blocks in the excavated zone (photo 4). In the beginning, these were recorded and numbered in the same way as the rest of the archaeological material. In this way, the dismantling of the blocks revealed the anthropic nature of this accumulation from the first year of the excavation. This observation was decisive for the rest of the excavation. From then onwards, the blocks were left in place in order to provide an overall vision and for ulterior study.

\subsection{3 - Research issues}

As the first year of excavation yielded abundant lithic material and revealed the presence of the hearth $\mathrm{F} 1$, a very clearly structured element, we decided to orient our research in two directions: firstly the systematic recuperation of the lithic material in order to obtain statistical cultural and chronological information; and secondly, the adaptation of our work method to a wider organization of the site. The ultimate aim of our research was to apply a palethnologic approach to the site by exploiting all the available data, combining excavation data with palaeoenvironmental studies. 


\section{3 - Presentation of the lithic series from site 1}

\section{1 - History of the study}

34 The following presentation is the summary of the analysis of the retouched lithic material carried out between the cessation of the excavation and the end of the year 1982. Already, significant work on refits enabled us to partially or totally reconstruct numerous armatures, which would have otherwise have been difficult to imagine. This analysis combines the description and the exact measurements of each retouched piece and was completed by statistical counts and distribution charts for the diverse categories of objects.

Photo 4 - Photomontage of the prehistoric site of Auvours (photo M. Allard).

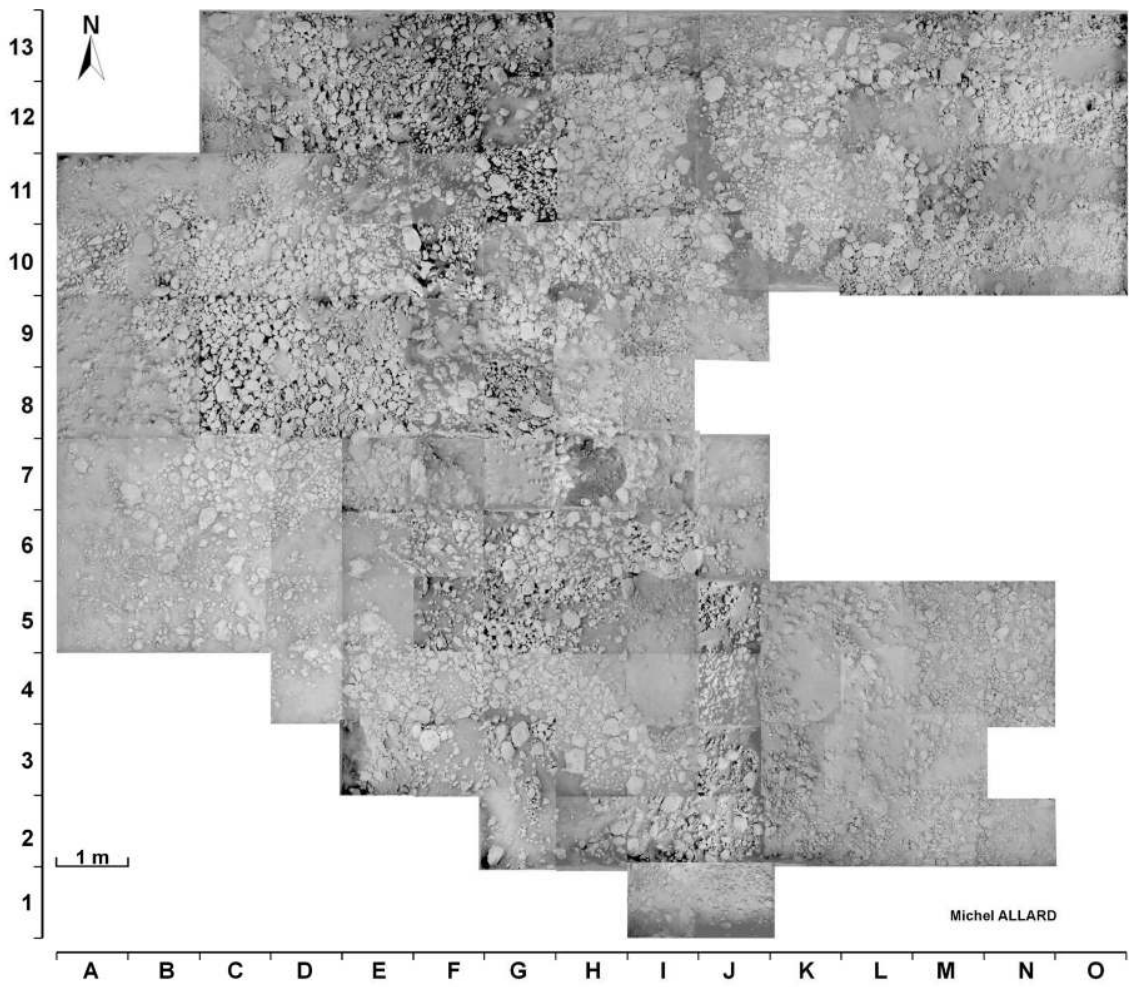


Figure 5 - Distribution of the knapped lithic material in the excavated zone.

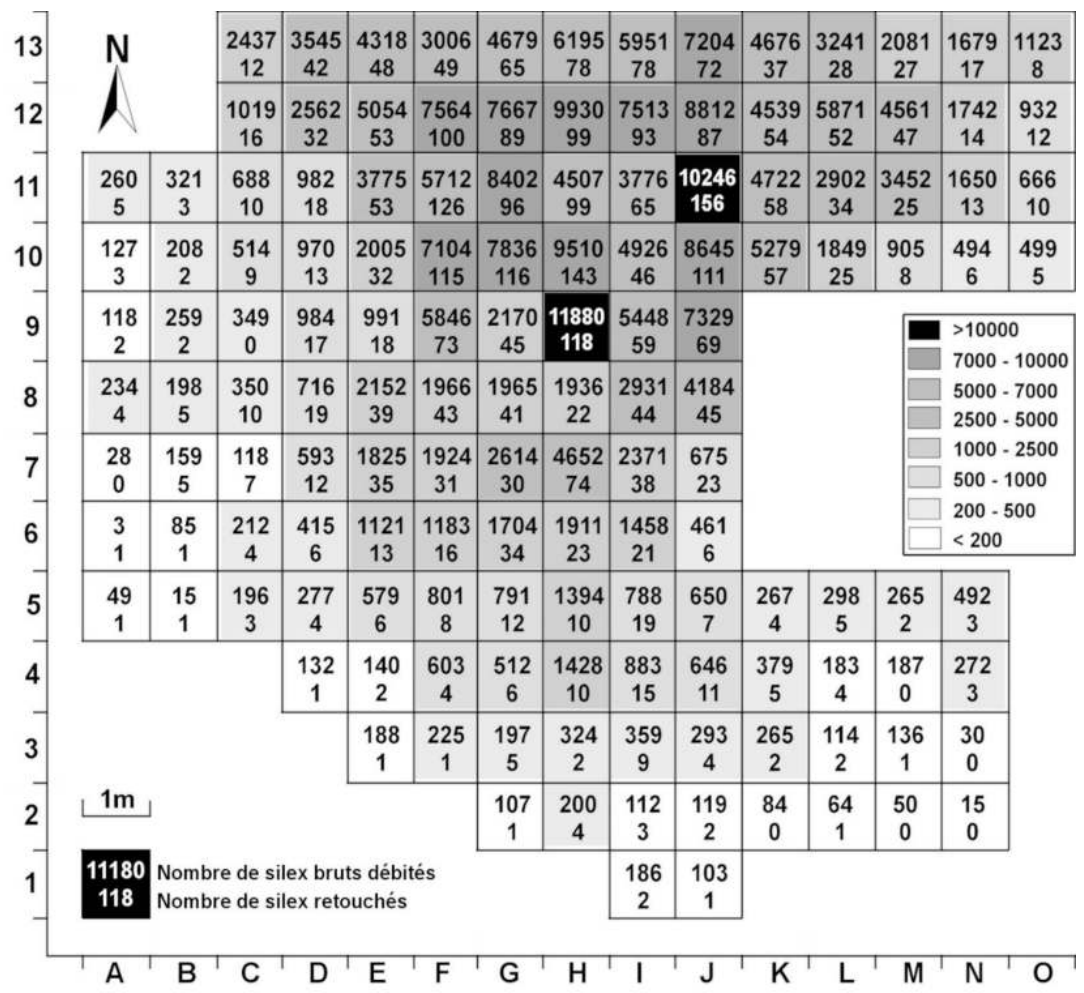

Due to space restrictions, only a tiny part of the thousand pieces drawn during the course of the years 1979 and 1980 are presented in this article.

As the technological study of the lithic industries from site 1 has been updated (Naudinot 2008), our presentation of the retouched pieces mainly concerns the observations and statistics made during the 1980s that were not included in the aforementioned technological study. These comprise in particular the end scrapers and certain armatures from the site.

\section{2 - General composition of the lithic series}

37 The prehistoric material from site 1 is exclusively mineral and includes a considerable quantity of knapped lithics (approximately 327,000 pieces), mainly represented by nonretouched pieces, including a significant proportion of micro-flakes and splinters. The concentration of these pieces in the northern half, where the density of objects can reach more than 10,000 flints per $\mathrm{m} 2$ (fig. 5), is cut off by the limit of the excavated zone. Colouring elements and charcoal were also recovered, as were several nonknapped lithic objects: grooved sandstone, balls.

\subsection{1 - The knapped raw materials}

Flint is the main raw material used and several qualities of flint are present at the site. Small blocks and plates of siliceous limestone were collected near the site and very often used for basic tools that do not require any particular qualities. A grey and white speckled flint of excellent quality, used for the fabrication of armatures and end 
scrapers, comes from further away. Several fragments of quartzite-sandstone, of unknown origin were also found at the site.

\subsection{2 - The cores and hammerstones}

214 cores, including 67 with internal cracking or thermal cupules due to heating, have been found. These modest-sized pieces present lengths ranging from $27 \mathrm{~mm}$ to $93 \mathrm{~mm}$ with an average of $47.5 \mathrm{~mm}$. Most of these are prismatic cores with one (25\%) or two (35\%) striking platforms. Their shape is sometimes cylindrical (fig. 6a), and generally appears to be compressed between a flattened debitage surface and a partly cortical back (fig. 6b). Other types of cores with alternate, intersecting or multiple striking platforms each represent $5 \%$ of the total. We only identified two bi-pyramidal cores, two polyhedral flake cores and one conical core. The debitage appears to be oriented towards a blade-bladelet type production. However, there is also significant flake production, some of which are covered in cortex and come from the initial reduction phases. Nonetheless, other products bearing cortex seem to have been knapped without prior cortex removal and are very small in size.

In spite of the profusion of objects and the presence of many cores, no hammerstones were found at the site. Moreover, the study of the blade-bladelet blanks with systematically abraded butts indicates that these products were not knapped with antler or wooden hammers. This implies that the hammerstones were in soft stone, as suggested by the close proximity of limestone sources, or that the hammerstones were removed from the site. Unfortunately, due to the very siliceous nature of the soil, we cannot advance a conclusion.

Figure 6 - a - Prismatic core with opposite striking platforms. b- Flattened core with two striking platforms (drawings M. Allard).

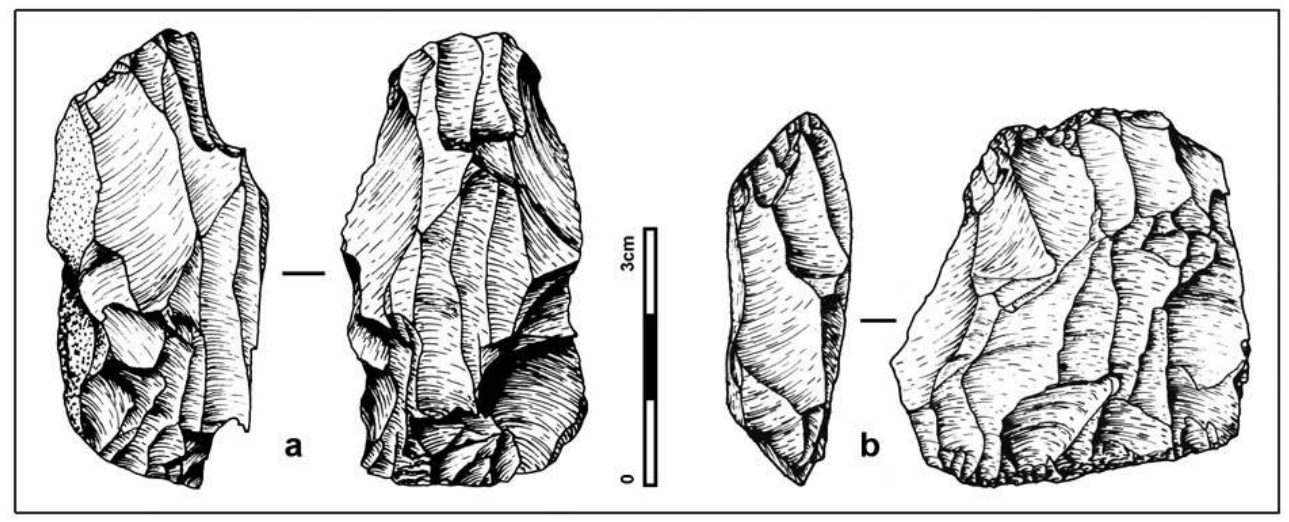

\subsection{The retouched lithic material}

The inventory comprises nearly 4,200 retouched lithic pieces, or $1.28 \%$ of the total number of pieces from site 1 . This count was reduced to 3,899 pieces after carrying out refits and connections (tab. 1). Three-quarters of these pieces, made up of very fragmentary backed bladelets, resulted in the finding of approximately 300 connections. 
The end scrapers comprise 244 simple tools and 365 arcs if we take account of the double and composite tools.

3 The burins are represented by 231 pieces presenting 314 bevels if we include the multiple and composite pieces.

44 These counts underline the relative balance between the burins and the end scrapers with an end scraper/burin ratio of slightly over 1 , when we calculate it with the classical method $(244 / 231=1.05)$, but a lower ratio when we include the multiple and composite elements $(274 / 322=0.84)$.

This proportion of burins adds a clear Palaeolithic character to the series.

Unlike for the non-retouched series, the retouched objects contain a preponderant proportion of blades and bladelets. In particular, the armatures were all made on bladelets, or on small blades reduced by retouch.

Table 1 - Breakdown of the retouched pieces.

\begin{tabular}{|l|c|c|}
\hline Catégorie & Nombre & $\%$ \\
\hline Grattoir & 244 & 6,25 \\
Burin & 231 & 5,92 \\
Outil composite & 32 & 0,82 \\
Perçoir ou bec & 29 & 0,74 \\
Lame à bord abattu & 3 & 0,07 \\
Lame, retouche continue & 3 & 0,07 \\
Encoche & 39 & 1 \\
Denticulé & 9 & 0,23 \\
Raclette & 23 & 0,58 \\
Lame ou éclat tronqué & 90 & 2,3 \\
Pièce bitronquée & 12 & 0,3 \\
Lamelle bitronquée & 153 & 3,92 \\
Microperçoir & 101 & 2,54 \\
Lamelle à encoche & 41 & 1,05 \\
Triangle & 4 & 0,1 \\
Lamelle à dos et/ou troncature & 2844 & 72,94 \\
Divers & 41 & 1,05 \\
Totaux & 3899 & 99,85 \\
\hline
\end{tabular}

\subsection{1 - The end scrapers}

The 244 end scrapers (fig. 7) are generally located on the distal end of the blanks. The percentage of proximal arcs attains $13.2 \%$ (tab. 2). 
Table 2 - Study of the end scrapers.

\begin{tabular}{|l|c|c|c|c|c|c|c|c|c|c|}
\hline Type de grattoir & Nombre & \multicolumn{3}{|c|}{ Dimensions } & \multicolumn{3}{c|}{ Localisation du front } & \multicolumn{3}{c|}{ Orientation du front } \\
\hline & & $\mathrm{L}$ & $\mathrm{I}$ & é & Proximal & Distal & Axial & Dextre & Sénestre & Irrésolu \\
\hline G. raccourci & 94 & 27,7 & 23,5 & 7,67 & 9 & 85 & $37(41,5 \%)$ & $38(42,6 \%)$ & $14(15,7 \%)$ & 5 \\
G. brisé & 39 & & & & 9 & 30 & 3 & 5 & 1 & 30 \\
G. sur lame & 17 & 42,66 & 20 & 7,5 & 1 & 16 & 7 & 6 & 1 & 3 \\
G. double & 6 (12 fronts) & 32,8 & 25,66 & 9,66 & 6 & 6 & 0 & 2 & 2 & 2 \\
G. sur éclat & 56 & 37,1 & 28,13 & 8,8 & 2 & 54 & 30 & 22 & 2 & 2 \\
G. caréné & 9 & 43 & 21,25 & 0 & 1 & 8 & 0 & 5 & 3 & 1 \\
G. épaulement & 23 & 30,46 & 25,29 & 7,65 & 4 & 19 & & & & \\
\hline Totaux & 244 & & & & 32 & 218 & 77 & 78 & 23 & 43 \\
& & & & & $13,2 \%$ & $89,3 \%$ & $34,84 \%$ & $35,29 \%$ & $10,40 \%$ & $19,45 \%$ \\
\hline
\end{tabular}

Figure 7- End scrapers. Shortened scrapers: nos 1-18. Scrapers on blades: n" 19-20. Double scraper. no 25. Flake scrapers: nos 21-24. Keeled scraper. no 27. Shouldered end scraper. no 26 (drawings M. Allard).

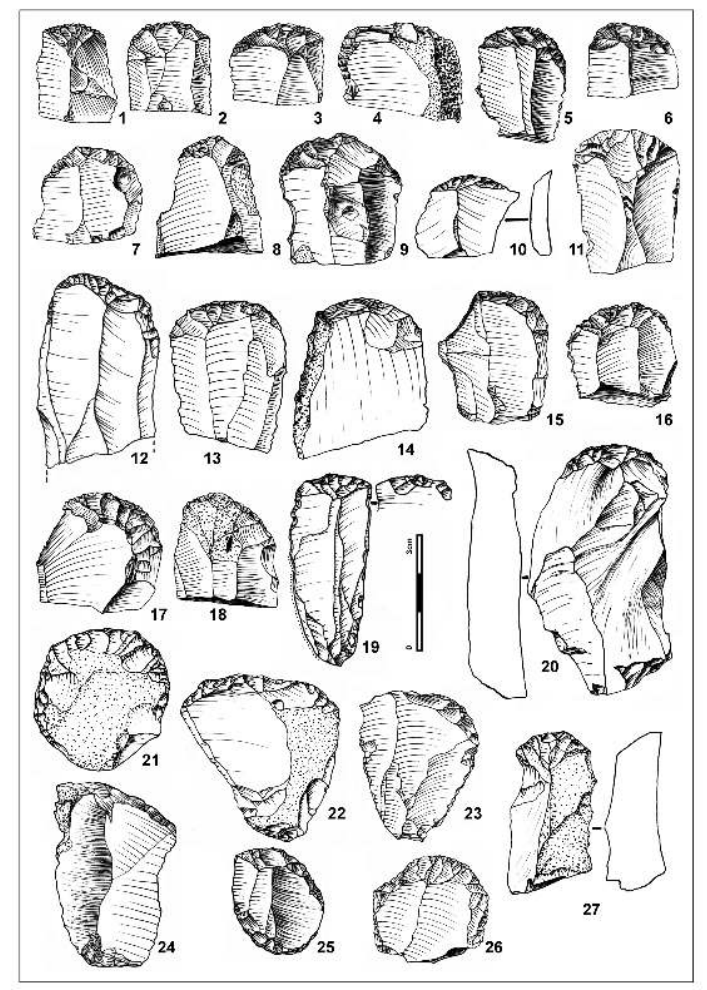

Four end scrapers presenting more or less splintered inverse retouch could have been used as adzes or as intermediary pieces for working hard materials.

Among the 273 end scraper arcs studied, 61 are skewed to the right and 14 to the left. On the simple end scrapers, the obliquity rate varies between 5 and $7 \%$ for the left and 21 to $27 \%$ for the right. This rate is higher for double end scrapers.

Several types of end scrapers (shortened end scraper, fan-shaped end-scraper, flake scraper) present a latero-basal retouch on one or more edges which may correspond to a hafting system.

The metric study of the end scrapers focused on the length (L), width (w) and thickness (th). The aim of this study was to provide elements for comparisons and possible links with other series. 


\subsubsection{1 - Shortened end scrapers}

These are end scrapers on fragments of blades or lamellar flakes where the end opposite the arc was fractured by direct or inverse flexure. The length of these pieces is less than twice the width. These tools, represented by 94 pieces, comprise the largest group of end scrapers, accounting for $37.75 \%$ of these tools (fig. 7, nos 1-18). For this reason, they are the best adapted tools to a statistical metric study.

The length of these tools varies between 25 and $30 \mathrm{~mm}$, with an average of $27.7 \mathrm{~mm}$.

The width fluctuates between 20 and $25 \mathrm{~mm}$ with an average of $23.5 \mathrm{~mm}$.

The thickness ranges from 4 to $13 \mathrm{~mm}$ with an average of $7.67 \mathrm{~mm}$ and a maximal frequency for a thickness of $6 \mathrm{~mm}$.

5 It also appeared interesting to measure the sagittal tilt of each end scraper on the plane side. This tilt varies between $35^{\circ}$ and $80^{\circ}$ and presents a maximum for the values comprised between $50^{\circ}$ and $60^{\circ}$. These results confirm the homogeneity of the series.

7 In addition, in $75 \%$ of the cases, the fracture opposed to the arc of the shortened end scraper is direct, that is to say, produced from the plane surface towards the dorsal surface of the tool. It can, in this case, present a tongue or a negative tongue or the dorsal side. Moreover, $40 \%$ of these end scrapers shortened by direct fractures present a tongue associated with splinters, demonstrating the violence of the shock that generated the break. This type of fracture appears to be difficult to apply to a handheld end scraper. On the other hand, a hafted piece could be thrown with enough force to produce a fronto-ventral shock capable of breaking the piece in this way (fig. 8). Lastly, about ten of these shortened end scrapers associated with a direct fracture also bear retouch or lateral or bilateral notches at the edge of the fracture. These could correspond to binding zones. All of these observations point to the hafting of these end scrapers. This would not be the case for shortened end scrapers with inverse fractures. suggests that the reused proximal parts are no longer identifiable. differentiated within this category of end scrapers: axial arcs (41.5\%) with an axis corresponding to that of the blank, offset to the right (42.6\%) and offset to the left (15.7 $\%$ ). The offset to the right type is dominant. If we associate the offset to the left end scrapers, the rate of lateralization of these end scrapers reaches $58.3 \%$.

The cortex present on more than a quarter of these end scrapers shows that these blanks correspond to the preliminary knapping of small flint nodules. 
Figure 8 - Possible mode of end scraper shortening by fracture (drawing M. Allard).

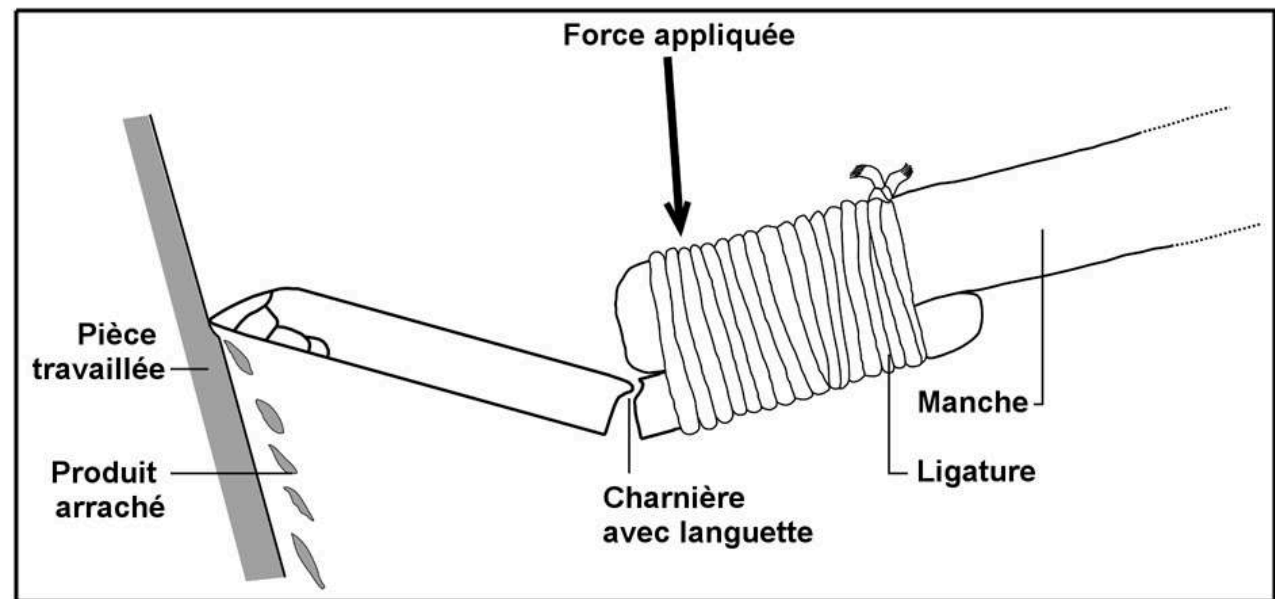

\subsubsection{2 - Other types of end scrapers}

61 Comparable studies were applied to the other end scrapers. The results are presented in table 2 .

\subsection{2 - Burins}

62 The rest of the toolkit (fig. 9) comprises a large group of burins, made up of 232 tools, presented in table 3. 
Figure 9- Tools. Offset dihedral burin: $n^{\circ} 1$. Multiple dihedral burin: $n^{\circ} 2-4$. Angle burin on break $n^{\circ}$ 5-6. Corbiac burin: $n^{\circ} 7$. Composite tool: $n^{\circ} 8-9$. Borer $n^{\circ} 11-13$. Blade with continuously retouched edge: $n^{\circ} 10$. Notch: $n^{\circ} 14$ Denticulate: $n^{\circ} 15$. Raclette: $n^{\circ} 16-18$. Truncated blade: $n^{\circ} 19$. Bitruncated piece: $n^{\circ}$ 20-21. Truncated bladelets: $n^{\circ}$ 20-21. Microborer. $n^{\circ} 24-26$. Triangles: $n^{\circ} 27-28$ (drawings M. Allard).

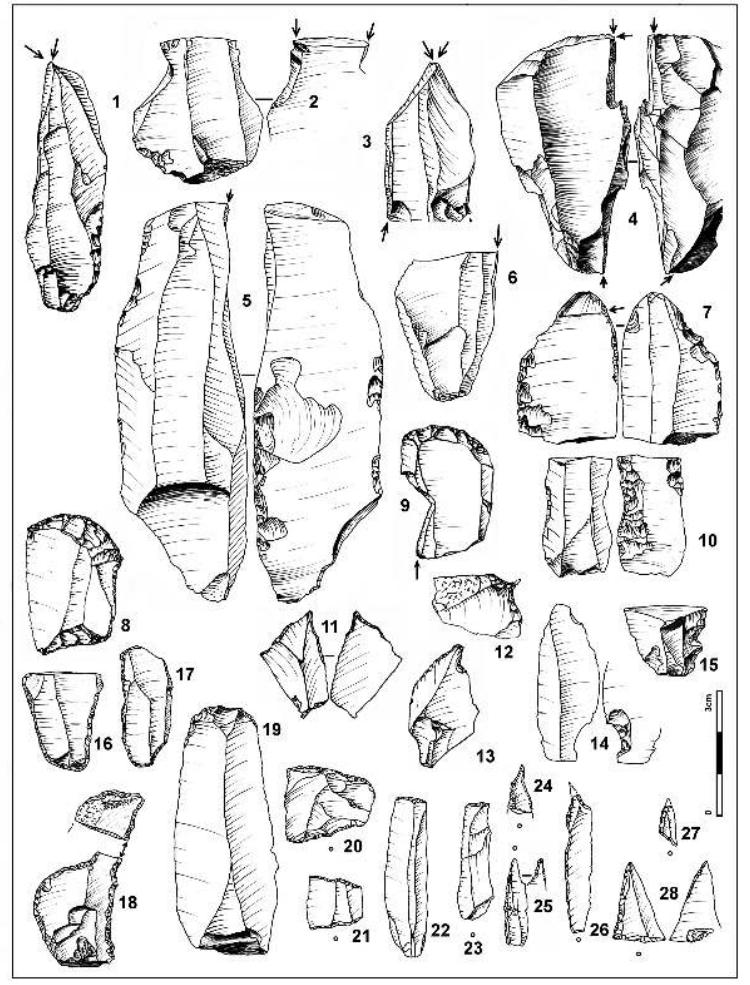

Table 3 - Breakdown of the burins.

\begin{tabular}{|l|c|c|}
\hline \multicolumn{1}{|c|}{ Type de burin } & Nombre & $\%$ \\
\hline Burin dièdre déjeté ou droit & 35 & 15,08 \\
Burin dièdre d'angle & 44 & 18,96 \\
Burin d'angle sur cassure & 84 & 36,2 \\
Burin dièdre multiple & 47 & 20,25 \\
Burin dièdre sur troncature & 8 & 3,44 \\
Burin de Corbiac & 6 & 2,58 \\
Burin multiple mixte & 8 & 3,44 \\
\hline Totaux & 232 & 99,95 \\
\hline
\end{tabular}

The abundant burins on fractures gave rise to diverse statistical measurements. The results concerning the width of the bevels did not appear significant. On the other hand, the unimodal diagram concerning the distribution of the angle measurements of the bevels seems to portray the homogeneity of the series (fig. 10).

Lastly, an angle burin on a break (fig. 9, $\mathrm{n}^{\circ}$ ) and a Corbiac burin (fig. 9, $\mathrm{n}^{\circ} 7$ ) present a strong inverse splintered retouch on one edge with no apparent association with the burin function. Studies and experiments on this type of retouch (Barton 1986) suggest that it is related to working semi-hard materials such as antler or wood. 
Figure 10 - Histogram of the bevel angle of angle burins on breaks.

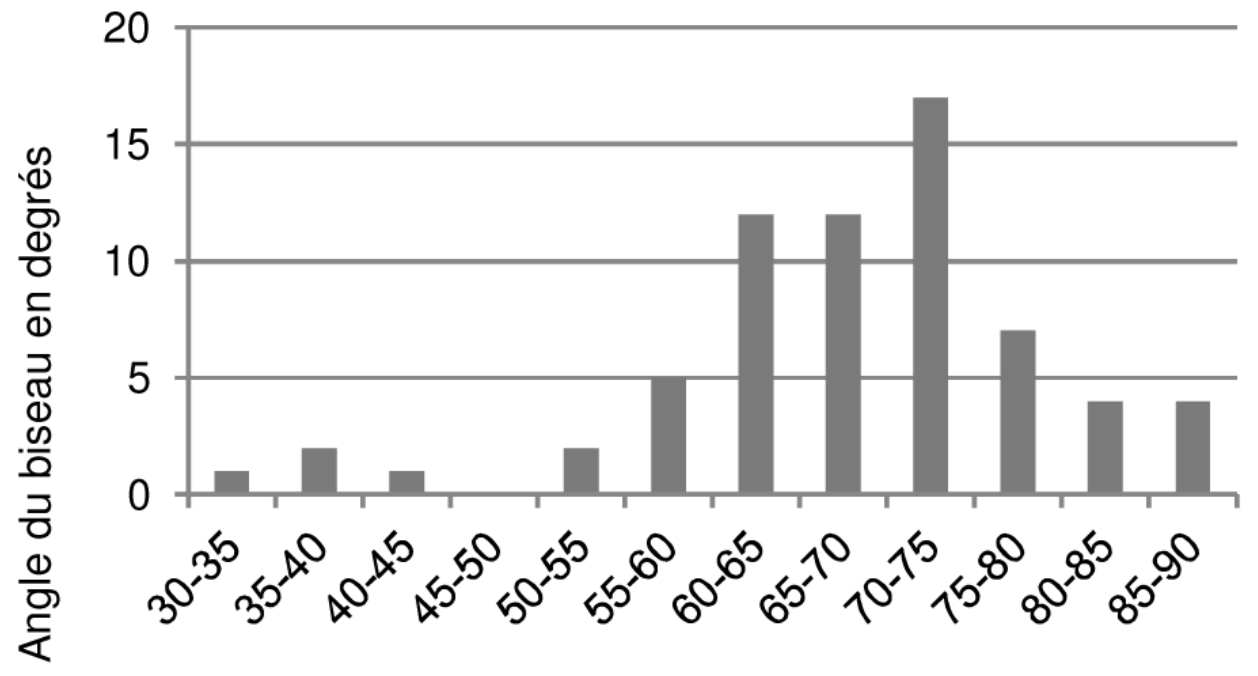

Nombre d'outils

\subsection{3 - Raclettes} comparable morphological and dimensional variability to those observed in the Badegoulian. We do not know what they were used for. In this case, the abrupt and used retouch could result from the abrasion of striking platform edges.

\subsection{4 - Backed lamellar pieces and/or truncation}

Table 4 - Distribution by category of backed lamellar pieces.

\begin{tabular}{|c|c|c|c|c|c|c|c|}
\hline \multirow[t]{2}{*}{ Lamelles retouchées } & \multicolumn{7}{|c|}{ Types de retouche } \\
\hline & \multicolumn{3}{|c|}{ Retouche à gauche } & Retouche indéterminée & \multicolumn{3}{|c|}{ Retouche à droite } \\
\hline Fragments & $\begin{array}{c}\text { Distal } \\
173\end{array}$ & $\begin{array}{l}\text { Mésial } \\
258\end{array}$ & $\begin{array}{l}\text { Proximal } \\
225\end{array}$ & 52 & $\begin{array}{c}\text { Distal } \\
496\end{array}$ & $\begin{array}{l}\text { Mésial } \\
695\end{array}$ & $\begin{array}{c}\text { Proximal } \\
912\end{array}$ \\
\hline Total fragments & \multicolumn{3}{|c|}{656} & 52 & \multicolumn{3}{|c|}{2013} \\
\hline Pièces entières & \multicolumn{3}{|c|}{68} & & \multicolumn{3}{|c|}{129} \\
\hline Total par catégorie & \multicolumn{3}{|c|}{724} & 52 & \multicolumn{3}{|c|}{2232} \\
\hline
\end{tabular}

67 This category encompasses 3,008 pieces and is by far the largest group of retouched pieces. It is mostly made up fragments of fine backed bladelets for which we looked for refits. We identified two categories, backed pieces and/or right hand truncations and backed pieces with/or left hand truncations. Within these two categories, distal, mesial and proximal elements were separated in order to simplify the search for possible refits 
(tab. 4). This classification brought to light the numerical preponderance of backed pieces/and or right hand truncations and enabled us to carry out numerous refits, thereby reducing the total number of pieces in the series to 2844 .

\subsubsection{1 - Backed points and/or truncations}

This series contains 725 points, including about 150 whole pieces. The rest are fragments. Each whole or fragmentary piece was oriented in the same way as the blank and the separation of the distal and proximal fragments shows that $89.5 \%$ of the points were made on the more robust proximal end.

The microscopic study of the fractures indicates that $76.7 \%$ of the fractures are adjacent, on the hinge side, to the beginning of a tongue, referred to here as a "prototongue". This feature probably results from an apical percussion of the piece in an axial direction. Moreover, the pressure applied to the hinge during the ultimate detachment stage could have caused the removal of very small splices, referred to as "esquillures" or splinters. These develop on the ventral or dorsal edge beside the hinge. Figure 11 presents details of the observations made on refitted fragments. The systematic nature of these fractures could be linked to the fact that these bladelets are very thin. These proto-tongues and splinters do not appear to have been observed on thicker armatures, used as javelin heads. On the other hand, fine and light bladelets may correspond to arrow heads.

Figure 11 - Schema of a fracture of a bladelet with proto-tongue and fractures according to our observations (drawing M. Allard).

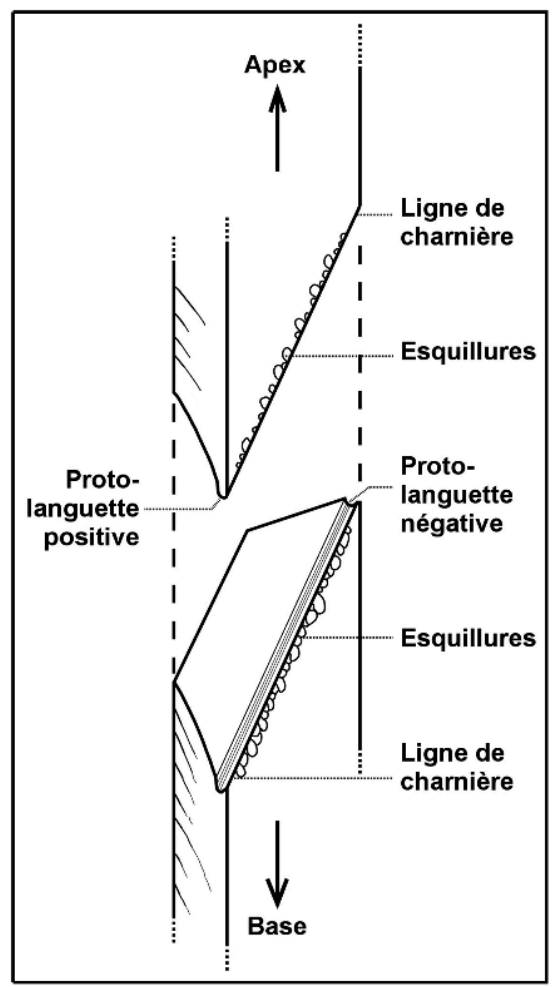

On other point fragments, fractures with no percussion marks could partly result from trampling. 
71 Based on these observations, we established a table of the classification of the points (tab. 5) and an inventory of the main types of armatures at the site (tab. 6).

Table 5 - Result of the sorting of the points. (Tableau 6)

\begin{tabular}{|l|c|c|c|c|c|}
\hline \multicolumn{1}{|c|}{ Catégorie } & \multicolumn{2}{|c|}{ Pièces proximales } & \multicolumn{2}{c|}{ Pièces distales } & Total \\
\hline & Dos à gauche & Dos à droite & Dos à gauche & Dos à droite & \\
\hline Élément apical de pointe dont pièce & 81 & 568 & 33 & 43 & 725 \\
avec languette et/ou esquillures & $53(65,40 \%)$ & $442(77,80 \%)$ & $28(84,80 \%)$ & $33(76,7 \%)$ & $556(76,7 \%)$ \\
Pointe des Blanchères & & & & & \\
Pointe à troncature oblique & $44(14,47 \%)$ & $239(78,6 \%)$ & $7(2,40 \%)$ & $14(4,60 \%)$ & $304(41,93 \%)$ \\
Pointe indéterminée & 16 & 85 & 13 & 23 & $137(18,90 \%)$ \\
\hline
\end{tabular}

72 The Auvours points are smaller than their counterparts from the site of Blanchères (Rozoy 1978) (Valentin 1995). This miniaturization may be linked to the difficulties involved in flint provisioning or to the small size of the flint nodules.

\subsubsection{2 - Auvours armatures with a non-retouched apex}

73 The discovery of percussion marks on the points incited us to pursue our research on all the retouched bladelets. This led, in particular, to selecting a series of 438 fragmentary and proximal bladelets with a concave back or a notch near the butt which may have been used for attaching them (fig. 12, $\mathrm{n}^{\circ}$ 43-58). The latero-proximal retouch on these pieces often forms a small spur beside the butt that could have facilitated attaching the tool to a shaft. When this retouch does not continue until the butt, the natural edge of the bladelet can form the spur (fig. 12, nos 46, 50). In rare cases, the basal retouch of the spur entails the removal of the butt (fig. 12, nos 54,58$) .75 \%$ of these proximal fragments present proto-tongues on their breaks (141 cases) and splintering (197 cases), identical to those observed on the basal fragments of points. They appear to belong to armature bases. Moreover, the few whole pieces in this category present a fine natural distal end, generally with a cutting edge.

The almost systematic absence of distal parts tends to accredit the hypothesis that only the proximal parts were brought back to the camp to be changed after breaking the armatures during hunting. There is however, one exception (fig. 12, $\mathrm{n}^{\circ}$ 57): two fragments of the same piece were refitted. The proximal fragment of this piece bears esquillures whereas the distal fragment, with a natural cutting end, was backed before the apex was broken once again. It is surprising that such pieces existed at Auvours. It is possible that they have not been recorded as they could have been considered as preforms.

75 The frequency of these pieces at the site tends to justify the appellation "Auvours armature with a non-retouched apex", advanced in the title to describe them. However, it would be preferable to renew and complete the study of these pieces as they suggest a diversification of hunting activities geared towards small game.

\subsection{5 - Chronocultural attribution}

The results of the typological and statistical studies are remarkably convergent. It appears that the toolkit from site 1 of Auvours is part of the Epipalaeolithic, or even linked to the transitional industries of northwestern Europe, broadly parallel to the Azilian (Allard 1977- p.12). This attribution can be further explained today. The bitruncations and the development of the principle of truncation could be an 
important cultural element in the diagnosis of this techno-complex" (Naudinot 2008 p. 264). This is also suggested by L. Detrain: "Given the lithic industry illustrations (fig. 7, 9 and 12), the lithic series from Auvours appears to be part of the Azilian technocomplex, with rectilinear backed points. It could even bear certain affinities with the Belloisian. Piece $\mathrm{n}^{\circ} 21$ in figure 9 is reminiscent of the bitruncations in the industries from the recent Dryas (Epilaborian, for example). This was brought to light in particular during the 2010 CPF and seems to be a western European tendency".

\section{4 - The non-knapped lithic pieces}

\subsection{1 - Grooved sandstone}

77 Two grooved pieces in reddish sandstone are the only grooved pieces found at the site (photo $5 \mathrm{~b}$ ), and were in the F1 hearth. The maximum dimensions of these pieces are $55 / 40 / 18 \mathrm{~mm}$ for the first and 35/43/16 $\mathrm{mm}$ for the second. These pieces are semicylindrically shaped with a plane surface with a single wide median groove oriented lengthwise, and a more or less curved surface. Comparable pieces, documented by J.-G. Rozoy (1978) during the final Palaeolithic and the Mesolithic, are more frequent during recent prehistoric periods. According to the latter author, they could have been used to smooth spear shafts or arrows. Indeed, the grooved sandstone pieces from Auvours, with low cohesion between the grains, present abrasive qualities adapted to materials such as wood. In accordance with the hypothesis advanced by J.-G. Rozoy, the analysis of these pieces and their place of discovery suggest that their plane surfaces could have been used pressed against each other around a previously heated wooden shaft (to soften the wood fibres), in order to straighten and standardize them. The available space between the grooves would have been suited to an arrow shaft with a diameter of about $8 \mathrm{~mm}$. This hypothesis can thus be related to the use of a bow at the site, as mentioned above. 
Figure 12 - Armatures. Blanchères points: nos 1-14. Points with an oblique truncation: nos 15-26. Points with a truncated base: nos 27-32 including Malaurie points: nos 27-28 and Istres points: nos 29-32. Segments: nos 33-36. Cheddar points: nos 37-40. Petersfeld points: nos 41-42. Armatures from Auvours: nos 43-58 (drawings M. Allard).

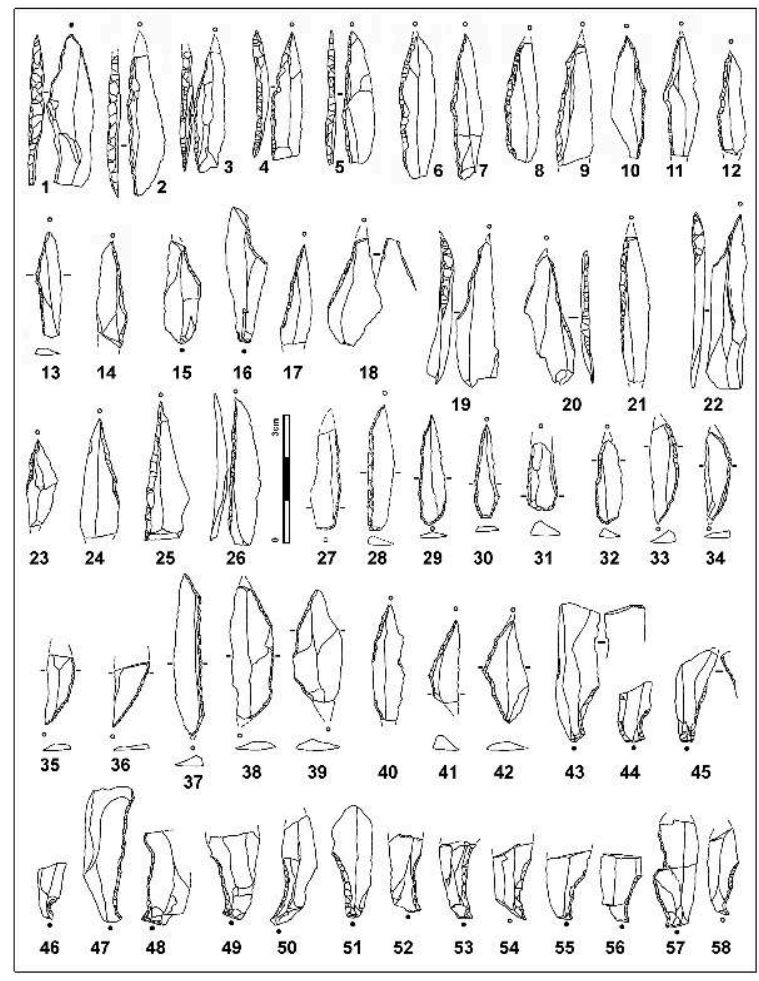

\subsection{2 - Stone balls}

At the southern limit of the excavation, in the adjoining squares 2-L and 2-M, two natural balls in reddish sandstone, with an average diameter of $2 \mathrm{~cm}$ were found (photo 5a). In his study of "the Periglacial in the surroundings of the Mans", G. Mary explains: "reddish sandstone balls: these are small round or ovoid pebbles with a diameter of 2 to $3 \mathrm{~cm}$, with used quartz and with the sheen of other aeolian sandstone balls" (Mary 1964 - p. 81). The morphology and dimensions of these pieces, as well as their proximity at the site (less than $1 \mathrm{~m}$ apart) could point to a recreational use, but it appears difficult to attribute a specific function to them in this prehistoric context.

\section{5 - Ochre material and distribution}

This material is abundant at the site and is not ochre in the strict sense of the term but a mixture of sand and ferruginous silt hardened into fine plates (photo $5 \mathrm{c}$ ). The geographic origin of this material has not been identified but it could come from the surrounding Tertiary formations. Although the colour of this material at the site is generally brown-red, two samples (squares 8-H, 8-D) display yellowish zones, while five others are entirely yellow and reveal the presence of limonite. As limonite becomes red hematite when heated, the brown-red colour observed on most of the plates would not a priori be natural, but result from prolonged contact with fire. As no mineralogical study was conducted, we do not know the exact nature of the red pigment. However, according to M.-P. Pomiès (1997), the presence of maghemite (a variety of hematite) 
was identified in the reddened samples, which could represent proof that they were transformed by heat.

Photo 5 - Non-knapped lithic objects. 5a: Stone balls, 5b: Sandstone polishers, 5c: Ochre material (photo M. Allard).

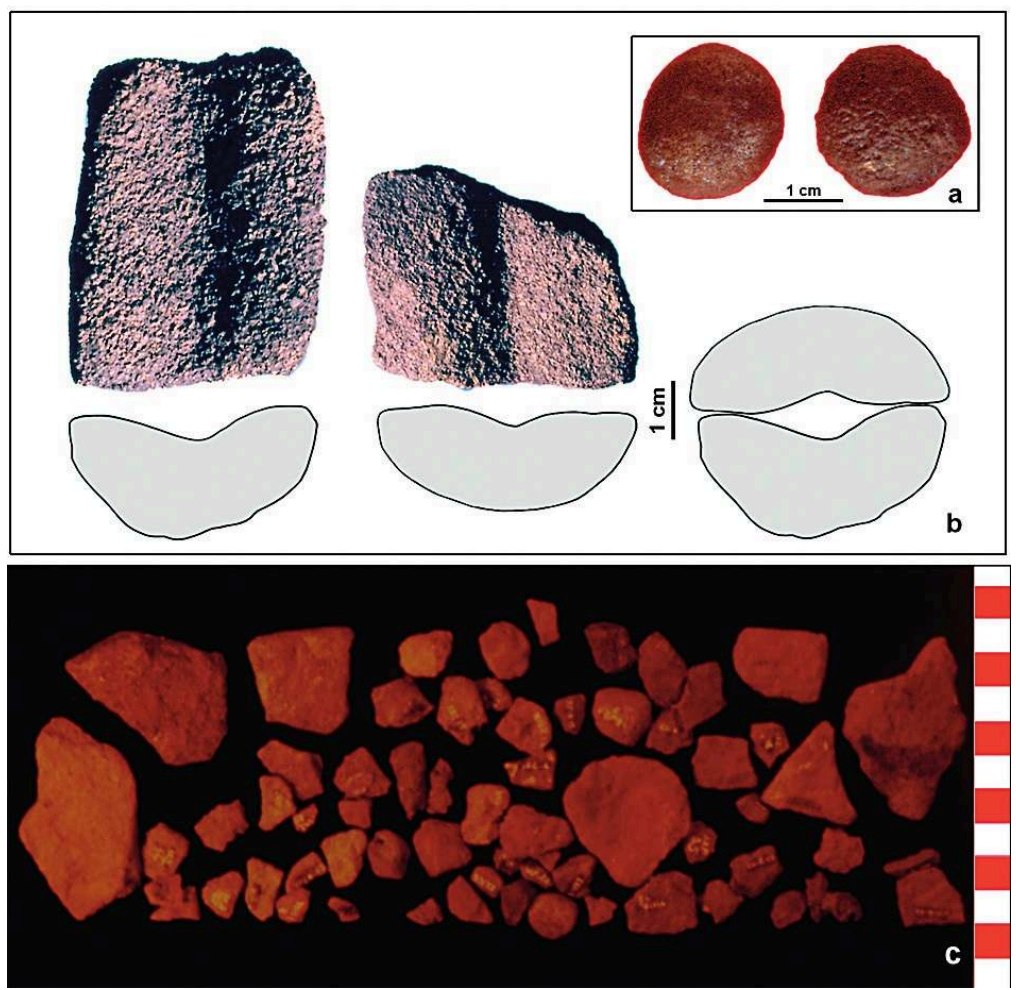

\section{6 - Charcoal and 14C dates} charcoal visible to the naked eye. After wet sieving, tiny charcoal fragments floated to the surface but these were too crumbly to be recuperated. The lithic objects present in these hearths indicate a post-Azilian chronocultural attribution. charcoals were directly sampled from a hollowed-out combustion layer, 12 to $15 \mathrm{~cm}$ thick, comprising two levels and located below the post-Azilian archaeological level (cf. $\S 4.4 .6)$.

The C14 analyses conducted by the Gif-sur-Yvette laboratory on the collected charcoals gave the following results:

- upper level (6.88 g sampled in 11-F and 12-F), 6,600 \pm 160 years BP (Gif., 3,989)

- lower level (23.9 g sampled in 12-F), 6,460 \pm 160 years BP (Gif., 3,990)

These dates demonstrate a more recent age than the post-Azilian archaeological layer, indicating a stratigraphic inversion. Given the concave shape of the charcoal layer, this could be explained by the presence of a deep fireplace, after the Post-Azilian, hollowed into the post-Azilian archaeological level. The progressive collapse of the post-Azilian layer would thereby have covered the charcoal layer with post-Azilian objects. 


\section{4 - The structured elements from site 1 at Auvours}

\section{1 - Generalities}

84 In 1972, the first excavation season brought to light a hearth, F1, with abundant archaeological objects, built with sandstone blocks. This essential discovery determined the continuation of the excavation and vertical photos were taken of each square, showing visible in situ blocks (photo 6).

Photo 6 - Captioned photomontage of the prehistoric site of Auvours (photo M. Allard).

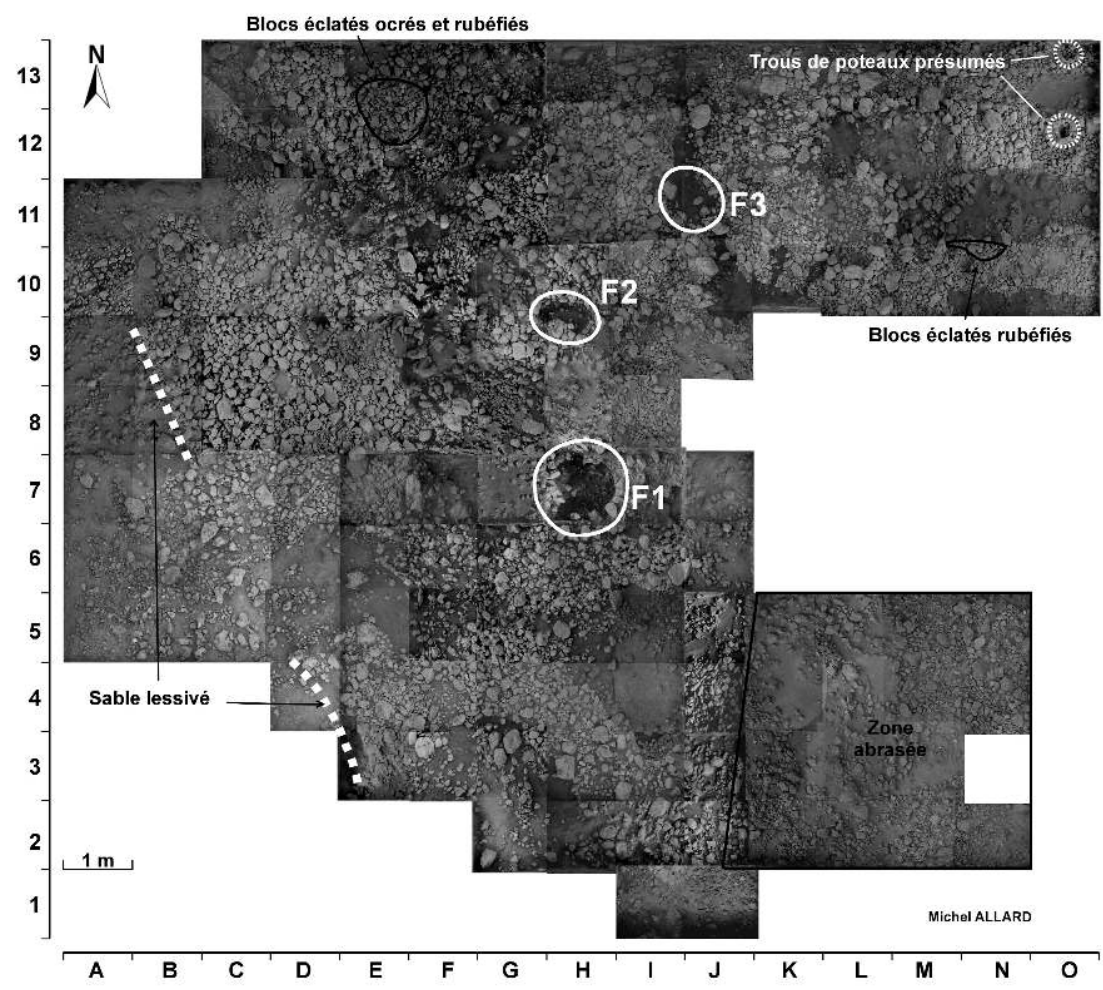

The photomontage presents the whole excavated surface with diverse accumulations of blocks.

With the help of observations carried out during the excavation and the appropriate iconographic elements (photos, plans, sections), we endeavour here to provide the necessary elements for the understanding of this photomontage. Note that sites 2, 3, 4 and 5 do not appear to contain blocks. It thus seems that the abundant blocks present on site 1 were decisive for the choice of site location. The prehistoric occupants of this site would have implanted their site elsewhere if this place had not suited them. 
Photo 7 - Hearth F1 showing hearth structures during study and dismantling in 1972 (photo M. Allard).

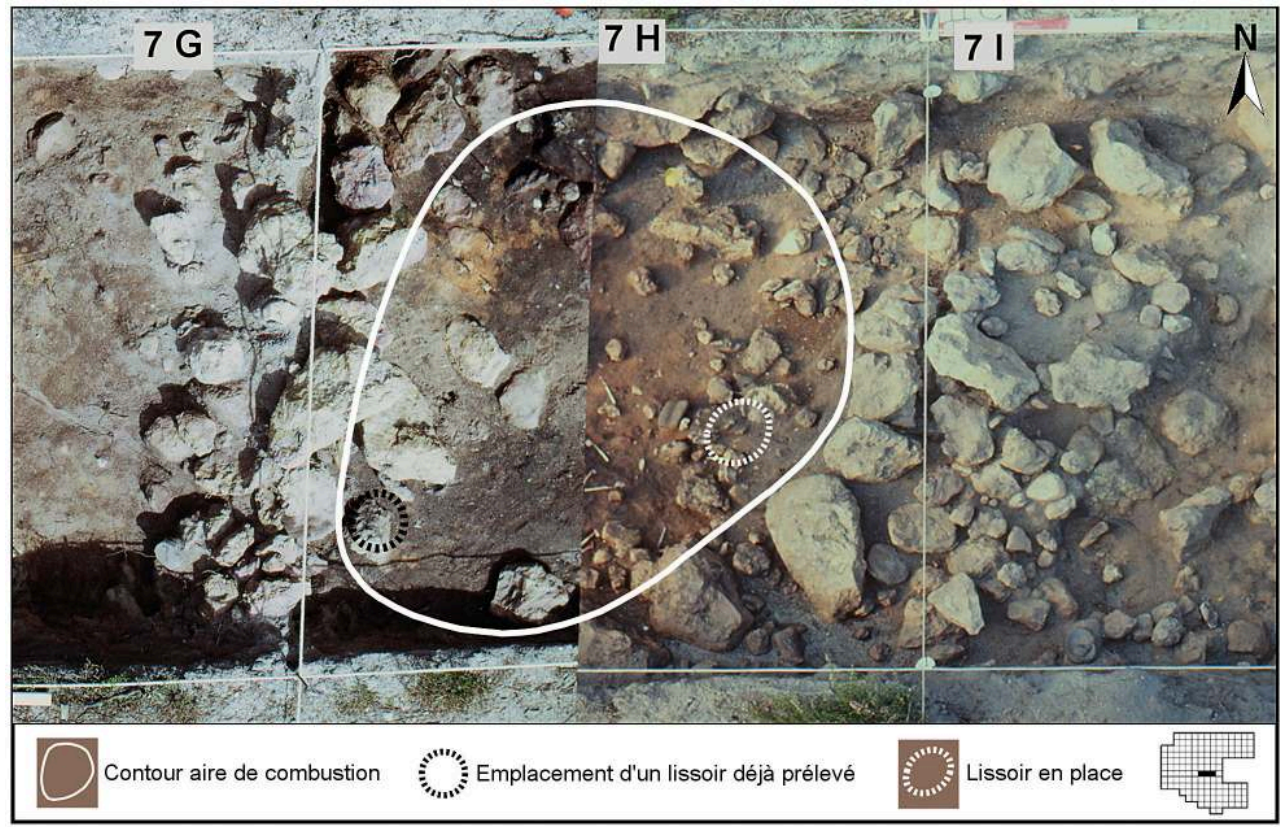

\section{2 - Analysis of the entirely excavated structured hearths}

After the discovery of the hearth $\mathrm{F} 1$, the continuation of the excavation brought to light two other combustion units named F2 and F3. The identification of these hearths was based on several criteria: their organization, the combustion products they contained or that were found nearby, and any possible thermal effects on the surrounding areas. They were totally excavated.

\subsection{1 - Hearth F1}

88 The combustion structure F1, excavated and dismantled during the first year of excavations, is almost centrally located in the studied zone (photo 7). It is part of the square $7-\mathrm{H}$ which contained 4,652 flints, including 74 retouched pieces. The diameter of the combustion area is $75 \mathrm{~cm}$ and this was surrounded by a crest of blocks about $35 \mathrm{~cm}$ high. At the exterior of the hearth, in square $7-G$, an area without blocks shows the perfect stability of the edge of the hearth on that side. The opposite edge is raised on a base of oblong blocks radiating out from the centre of the hearth. The centripetal extremities of several blocks were reddened by fire. Several of those found within the hearth seem to come from the boundary of the hearth.

Elsewhere, at about $40 \mathrm{~cm}$ from the ground surface, under a $15 \mathrm{~cm}$ thick combustion layer, several brown aureoles were recorded, showing the proximity of the BPh horizon to the podzol. Hearth 1 and the archaeological layer were thus entirely included in the eluvial horizon E. Some of the combustion products spilled over towards the northwest of the hearth, resulting in a change of direction in the crest of blocks. The internal part contains more abundant lithic objects than the external part, and enclosed the only two sandstone polishers found at the site (photo 5b). Lastly, on the south side, the combustion structure was leaning against a $3 \mathrm{~m}$ long pile of blocks, oriented west-east. 
It should be possible to reconstruct this hearth using the elements curated in the Mans Museum and the excavation plans, photos and drawings.

\subsection{2 - Hearth F2}

Hearth F2, with a diameter of about $40 \mathrm{~cm}$, is located at the centre of the squares $10-\mathrm{G}$, 10-H, 9-G, 9-H. It was perched on a sandy mound leaning against an imposing pile of blocks on the east side (photo 8). The central part of the hearth formed a small hollow filled with black-coloured combustion products over a thickness of $5 \mathrm{~cm}$. It was surrounded by blocks, apart from on the eastern side, which was open and acted as a discharge for emptying out products of the same colour. The base of the hollow was located between 25 and $30 \mathrm{~cm}$ below ground surface. The eastern edge of this hearth contained 12,000 flints, including 118 tools in one square metre and was the sector with the most abundant lithic objects (fig. 5). On the west and northwest side, the mound was bordered by a deep hollow, about $15 \mathrm{~cm}$ deep and $1 \mathrm{~m}$ wide. In square 9-F, this hollow formed a sort of channel containing grey-coloured ashes mixed with sand. The section of the hearth and the channel provide a more exact illustration of these data (fig.13).

Photo 8 - Hearth F2 with its central hollow surrounded by blocks and its draining channel (photo M. Allard).

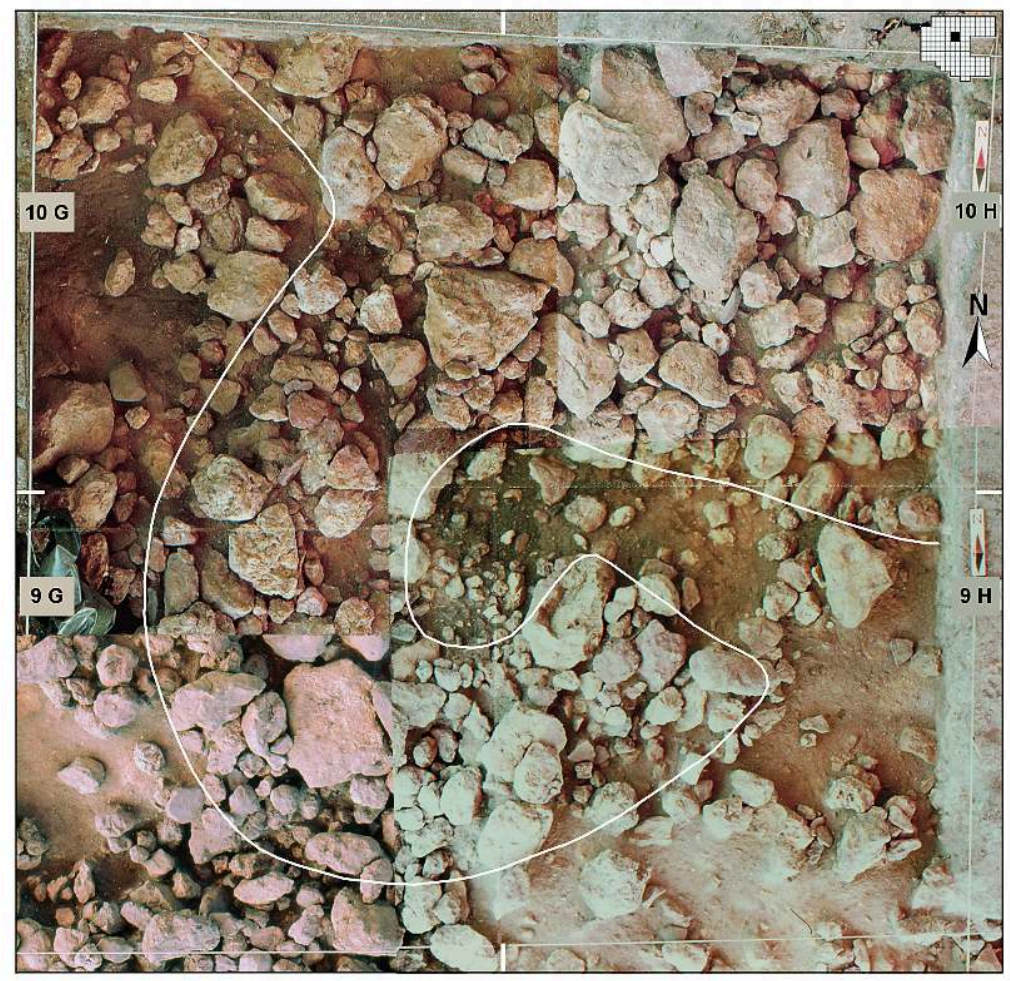


Figure 13 - Cross-section view of hearth F2. The west edge, in square 9-F, is marked by digging which carved out a sort of channel that continued northward until the P2 access (drawing M. Allard).

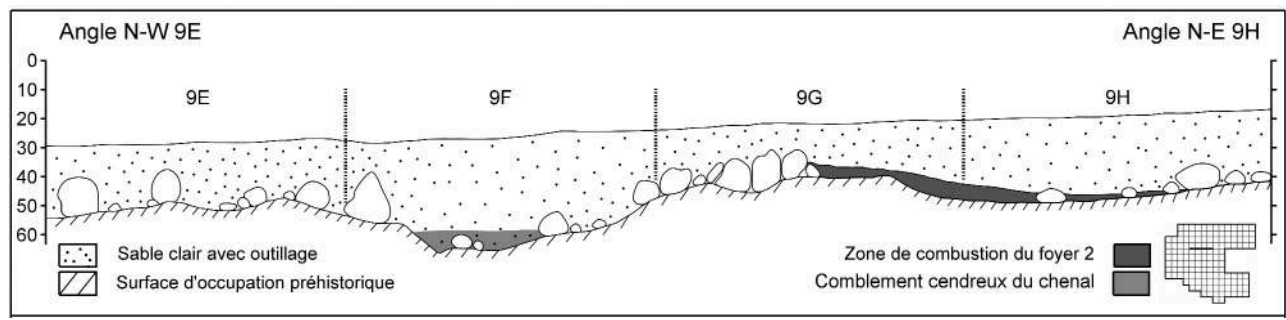

\subsection{3 - Hearth F 3}

The F3 hearth forms a hollow with a diameter of $60 \mathrm{~cm}$ at the centre of squares 12-I, 12J, 11-I, 11-J (photos 9 and 10), and contains a very dark-coloured combustion layer, about $10 \mathrm{~cm}$ thick. This zone yielded 30,347 flints, including 401 retouched pieces (fig. 8). The hearth continued towards the north through a long blowhole, the end of which was constricted by two large blocks in square 13-J. The combustion products discarded through this blowhole contained 7,204 flints, including 72 retouched pieces in square 13-J.

The hearth and its blowhole, implanted at the heart of a vast and thick accumulation of blocks, presented a blackish, sandy base, indurated $50 \mathrm{~cm}$ below the surface of the fire screen. At this depth, the base of the hearth, which was hollowed out in relation to the lateral stone lining, joined the black horizon BPh of the podzol. Although some of the combustion products were ejected through the blowhole, most of them were spread out from the hearth until squares 10-J, 9-J. This sector contained abundant ochre remains as well as a total of 15,974 flints, including 180 retouched pieces.

Photo 9 - Hearth F3. General vertical view obtained by photomontage (photo M. Allard).

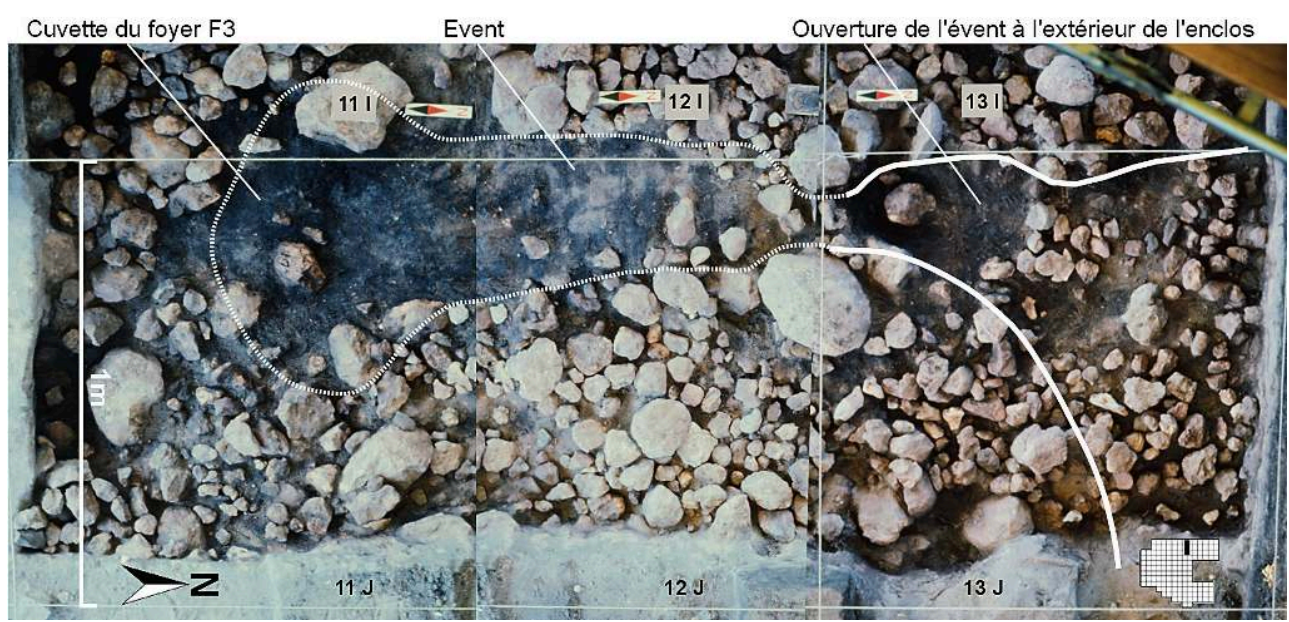


Photo 10 - Sector of hearth F3 seen from the east. This photograph provides an overview of the accumulations of blocks (photo M. Allard).

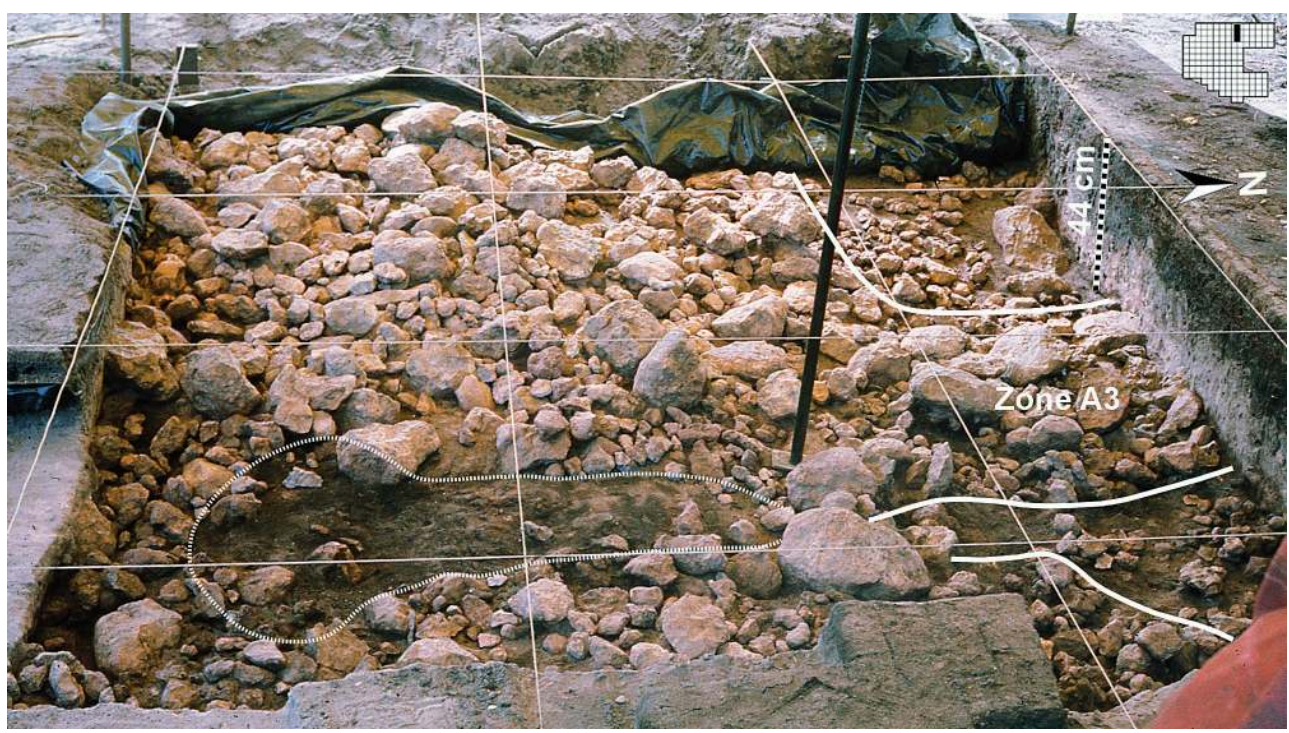

\subsection{4- Conclusion concerning the hearths F1, F2, F3}

by a crest of blocks. In contrast, the $\mathrm{F} 3$ hearth had been dug out until the black layer of the podzol among a major accumulation of blocks, forming a hollow with a blowhole. The loose, blackish combustion products from these hearths containing abundant lithic objects, produced a profusion of charcoal specks during flotation sieving, whereas the black and indurated sediment from the podzol observed at the base of F3 was totally sterile in this respect.

ince of knapped products around the hearth edges suggests significant flint knapping and retouch activities. The presence of objects inside the hearths could result from taking sand from around the hearth to throw into the fire to slow down combustion. This hypothesis has already been put forward (Allard 1982) and would account for both the abundance of lithic objects inside the hearths and the frequency of the thermal effects observed on them. circular cavity at the top with a diameter of 6 to $7 \mathrm{~cm}$. Small blocks bordering this cavity made up a slight bulge at the highest periphery. This layer was investigated over a thickness of $8 \mathrm{~cm}$, but only yielded a sandy sediment of the same colour as the rest of horizon $\mathrm{E}$ of the podzol, in which no traces of humus subsisted. Although 1,123 flints were found in this square, there were none in the cavity. A similar cavity was studied in the same conditions in square 12-0, at the top of another line of stones (photos 11 and 
12). We were intrigued by these remains and decided to preserve them intact, planning to continue the exploration of the cavities as part of renewed work on the site, which did not occur.

Therefore we did not reach the base of these two cavities, but the verticality of the internal walls and the good organization of the surrounding blocks suggest that these were wedges for vertical posts.

Photo 11 - View of the northeast part of the excavation, from its east border (photo M. Allard).

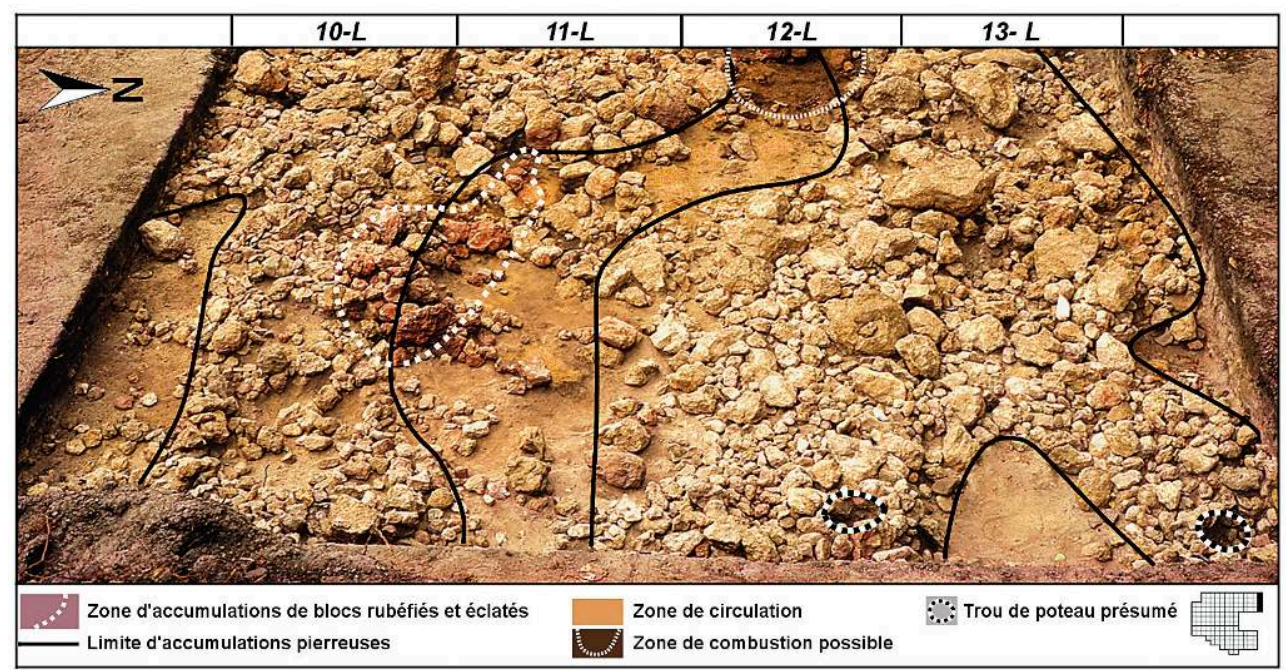

Photo 12 - Presumed post hole situated in square 12-0 (photo M. Allard).

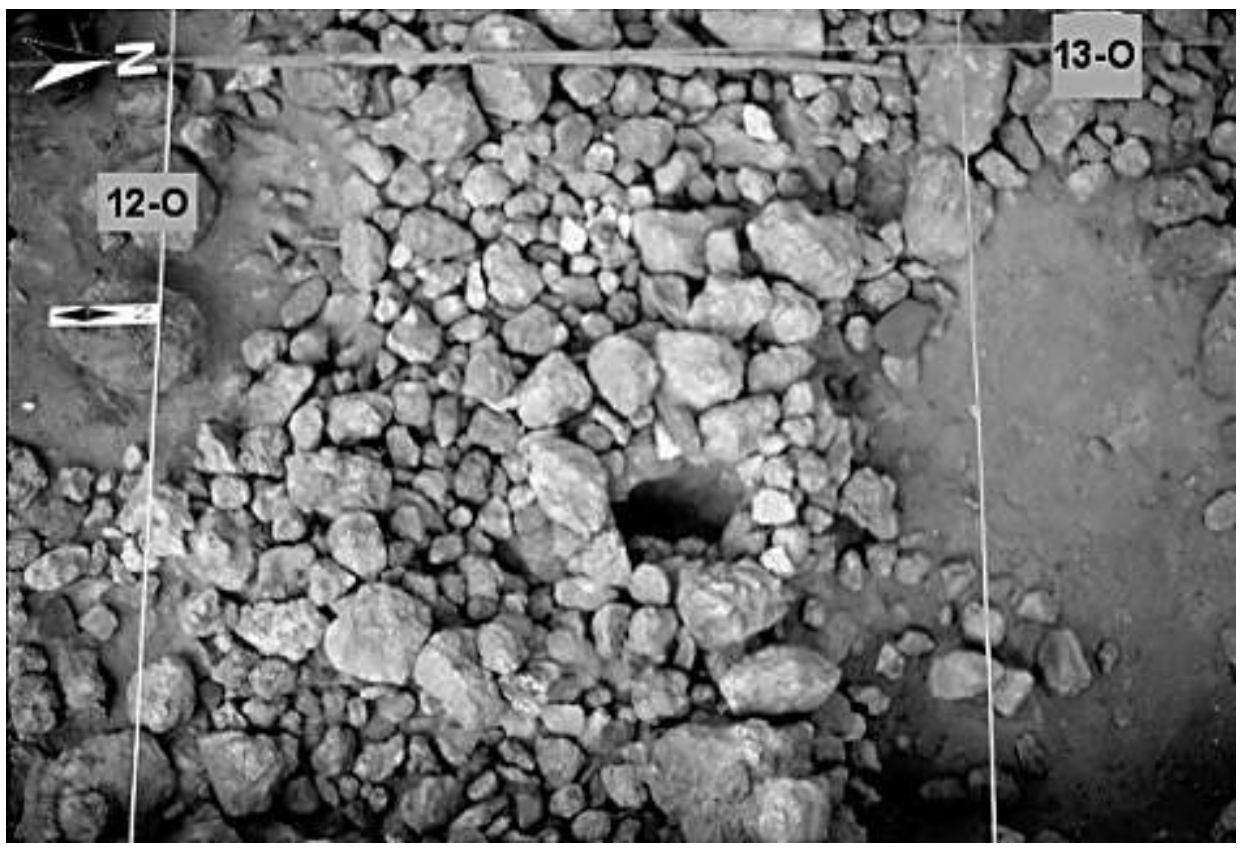

\section{4 - Additional observations}

The dismantling of the hearth F1 and the edging blocks accumulated on the west side (squares 7-E and 7-F) revealed the presence of lithic objects at the top of this 
accumulation, but the absence of objects in the internal part. This observation was decisive for the rest of the excavation and led to the preservation of block massifs in order to gain an overall vision of these structures.

\subsection{1 - Cryoturbation hypothesis}

The massive presence of blocks and structured hearths at site 1 at Auvours led us to question the origin of these piles of blocks. Were they the result of natural or manmade agents? This line of questioning gave rise to attentive field inspection. In particular, we observed two sections, twenty metres long and over a metre thick in the upper part of the low terrace. The first ran along the northern edge of the firewall between site 1 and the fallout from the terrace on the main Narais river bed; the second cuts into site 3 south of the track, resulting in the lowering of plot 291 (fig.1-b) in 1979. These sections were recorded outside paving zones in a mainly sandy formation and did not present any cryoturbation figures or ice wedges. Moreover, the many sections drawn during the excavation and the plan observations carried out from the surface of the firewall until the excavated zone did not reveal any traces of cryoturbation.

101 The geologist, G. Mary, who specializes in the Quaternary geology of this sector, recently restated that none of the cryoturbation or ice wedges affecting the high and middle terraces in the surrounding areas (Mary 1964 - p. 76) had been identified in the low terrace. Consequently, the hypothesis of the accumulation of the blocks from site 1 by cryoturbation is not backed up by any evidence and must therefore be ruled out.

Moreover, the elaborate structure of each hearth, such as the radiating layout of the blocks on the periphery of hearth 1 , the installation of hearth 2 in a hollow surrounded by blocks at the top of a small mound, the considerable depth of hearth 3 in the midst of a massif of blocks that does not result from natural phenomena, all show the anthropogenic organization of these combustion zones.

\subsection{2 - The southeast sector}

103 The southeast sector of the excavated zone was affected by a deeper stripping of the fire screen at the edge of the track, and was difficult to exploit from an archaeological point of view, particularly in bands KLMN where horizon E of the podzol containing the blocks had partially disappeared.

\subsection{3 - The northeast sector}

In the northeast sector, (bands KLMNO), photo 6 completed by photo 11, shows linear stone accumulations separated by areas with depleted blocks.

We differentiate:

- in the northeast angle (square 13-0), a line of blocks, with clearly marked edges, about $40 \mathrm{~cm}$ wide, $20 \mathrm{~cm}$ high, presenting what appears to be a post hole at the top. This band joins a more consequent linear accumulation of blocks in squares $12-\mathrm{N}$ and $12-\mathrm{O}$. The latter presents a clearly vertical north side. The presence of another similar post hole in square $12-0$, less than $10 \mathrm{~cm}$ from this northern side, shows the remarkable stability of the whole structure. In contrast, the southern edge of this pile of blocks has partly collapsed;

- south of these accumulations, squares $11-\mathrm{N}$ and $11-\mathrm{O}$ are intersected by a zone about $1 \mathrm{~m}$ wide, depleted in blocks. This zone continues to wind on until square 12-L where the 
blackened earth seems to correspond to the located of a destroyed hearth. Blackened combustion residues associated with ochre products are spread out from square 12-L until square 11-N and are bounded on the south by a group of shattered and reddened blocks. This zone without blocks contains a lot more prehistoric finds than the immediately surrounding areas and seems to mark a zone of circulation. This extends into squares $11-\mathrm{K}$, 11-L and 10-K, 10-L between two accumulations $25 \mathrm{~cm}$ high, with slightly collapsed sides (photo 6).

\subsection{4 - The southwest sector} each, spread out between squares 11-B and 2-J over a length of $11 \mathrm{~m}$. We noted that:

- the zone between squares 10-BCDE and 7-BCDE, presents a massive accumulation of blocks, with a complex shape, $5 \mathrm{~m}$ long and with an average width of $2 \mathrm{~m}$. Within this accumulation there are three small spaces with a diameter of about 10 to $15 \mathrm{~cm}$, with no characteristic shape but filled with sand

- squares 10-C, 9-D and 7-E - aligned and regularly spaced by a metre in the axial zone were not subjected to further research. In 7-B and 6-B, a less dense and lower heap of blocks about 10 to $15 \mathrm{~cm}$ high - marks a perpendicular break in the general lengthwise axis;

- the zone between squares 4-EFGH and 2-IJ contains a sinuous accumulation of blocks, $6 \mathrm{~m}$ long, $1 \mathrm{~m}$ wide and 20 to $25 \mathrm{~cm}$ high. Most of this accumulation lies along the same axis as the alignments observed in the previous accumulation. The edge (mainly square 4-E) forms an $\mathrm{L}$ hook orthogonal to the main axis, 10 to $15 \mathrm{~cm}$ high;

- the squares 4-E, 4-D and 3-E, at the edge of the accumulation of blocks, were marked by the presence of a white sand with no silty coating and with a coarse granulometry corresponding to the characteristics of leached sand. Over a distance of a little more than 1 $\mathrm{m}$, this marked out a hollow 3 to $4 \mathrm{~cm}$ deep and $20 \mathrm{~cm}$ wide. An identical observation was made over a distance of about $2 \mathrm{~m}$ in squares $9-\mathrm{A}, 9-\mathrm{B}$ and $8-\mathrm{B}$ at the edge of the accumulation of blocks (photo 6);

- the intermediary part, squares 6-CDEF and 5-CDEF, located between the two previously described contains a $4 \mathrm{~m}$ long band, nearly $2 \mathrm{~m}$ wide, depleted in blocks;

- the quantitative decrease in lithic finds to the west of these two accumulations of blocks (fig. $8)$, suggests a delimitation of the installation zone.

\subsection{5 - The northwest sector}

- In squares 11-ABC, a zone depleted in blocks presenting a narrowing in 11-DE extends sinuously until squares 13-GH. In the field, the difference in height made it easy to distinguish but this is more difficult on the photomontage (photo 6)

- At the northern edge of this sinuous zone, in the zone 12-CDE, 13-D, an accumulation of blocks, about $2.5 \mathrm{~m}$ long, $30 \mathrm{~cm}$ high in 12-E and $20 \mathrm{~cm}$ high in 13-D, divides into two branches of unequal width oriented towards the northwest angle of the excavated zone. On the eastern side, a heap of shattered, ochre-covered and reddened blocks, with a diameter of $1 \mathrm{~m} 2$ adjoins this.

- In squares 11-F, 12-F and 12-G, the sandy sediment is heavily ochre-stained. The salmon pink hue with charcoal stains fades out progressively towards the north of the excavated zone (squares 13-EFGH). The southern part of this sector is the most strongly coloured zone and contained many ochre granules and plates. It also contained a very high number of lithic pieces (> 7500 remains per $\mathrm{m} 2$, fig. 5 ). 
- On the south side, the zone depleted in blocks is delimited by two accumulations, one of which is described at the beginning of the paragraph 4.4.4., the other of about $3 \times 4 \mathrm{~m}$ forming a dome, including hearth F3 and bounded in the southwest by the hearth F2. This limit is marked in 13-H, 12-G and 11-F by cut off points, emphasized by the abrupt nature of the terrain and the neighbouring accumulations about $30 \mathrm{~cm}$ high. Similar interruptions are present in 11-CDE.

\subsection{6 - Observations relating to the northwest sector of hearth F2}

The sector between the hearth F2 and the square 11-F was first excavated until the accumulations of blocks, left in place (fig. 14). This operation brought to light a deeper grey ashy band in 9-F and 10-FG. The ulterior excavation of this band showed that the ashes filled a channel, $1 \mathrm{~m}$ wide and about 15 centimetres thick in the central zone. This band was followed from the mound of hearth F2 until the southern limit of square 11-F. In this zone, we observed a modification of the content of the channel, becoming more compact and darker. At the base of the channel, a layer made up of two levels emerged, with abundant charcoal products, becoming thicker towards the north, reaching a thickness of $15 \mathrm{~cm}$. The very indurated upper level, 5 to $6 \mathrm{~cm}$ thick, contained several charcoals of about $1 \mathrm{~mm}$. The brown and loose lower level was considerably thicker and contained abundant charcoals, some of which were almost $1 \mathrm{~cm} 3$. The dating of these charcoals is discussed in $§$ 3.6.

Figure 14 - Section 10-E, 11-G (drawing M. Allard).

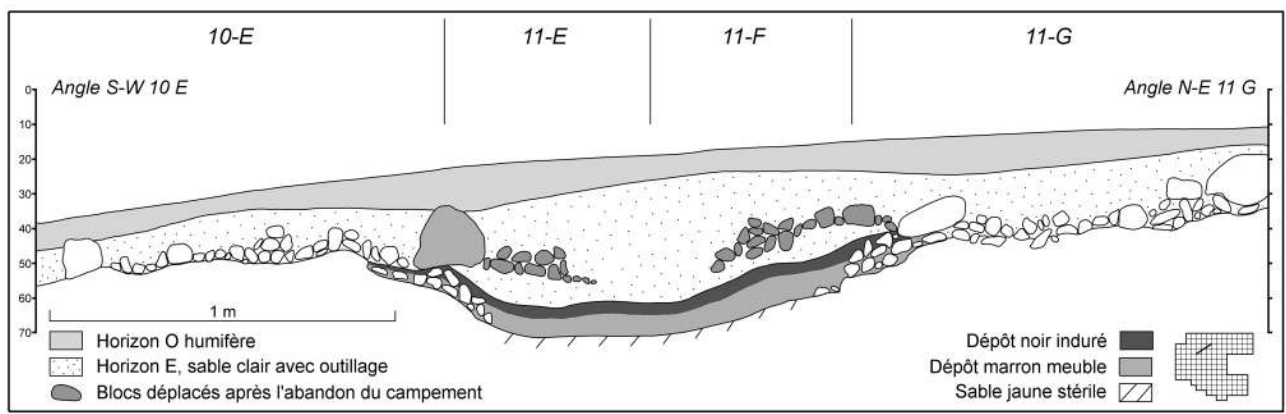

\section{5 - Relations between structures and prehistoric objects}

Although the excavation of site 1 at Auvours was not completed, the archaeologcial research enabled us to establish significant links between the structured elements and the lithic objects.

\section{Site boundaries}

The test pits provided information on the probable limits of the site towards the west $(\mathrm{S} 4, \mathrm{~S} 5)$, the south (S6) and the east (S2, S3). The test pit S1 in the heath north of the fire wall showed that the site continued in this direction. The excavation confirmed these observations and provided further details in spite of the effects of erosion since the site was abandoned by prehistoric groups. Furthermore, the gradual decrease in the 
number of objects indicates an intense activity zone around the hearths and highlights the presence of the long stony accumulation barring the southwest part of the excavation zone (fig. 5).

\section{Distribution of the archaeological material}

The archaeological material (327,000 flints) was mainly distributed in the northeast quarter of the excavation around combustion areas with major concentrations of knapping waste. However, the study of the distribution of the lithic material (cores, end scrapers, burins, knapped sandstone, ochre-covered plates, points, backed blade fragments and associations between knapped fragments) does not show any significant category clustering (fig. 15abc). Two adjustable grooved sandstone plates are however an exception, as they were found $60 \mathrm{~cm}$ apart in the F1 hearth.

\section{Presence of ochre-covered plates and ochre}

111 The brown-red colour of the ochre-coloured plates indicates that it is the result of heating (photo 5c). Although we cannot rule out a ritual use of ochre - body painting, the dyeing of ornamental elements and weapons, drawing on skin or bark, burials (Bordes 1952) (Triat 2011) - still practiced today by many human groups (LeroiGourhan 1955, 1976), it appears that the considerable quantity of pigment in the soil corresponds to a grinding workshop of ochre materials and/or possibly to a skin tanning centre using ochre for processing the skins. This hypothesis is in accordance with the abundant presence of end scrapers necessary for this work. 
Figure 15 - Distribution map of lithic objects. 15 a: Cores, scrapers, dihedral burins, burins on truncations. $15 \mathrm{~b}$ : Sandstone and ochre plates. $15 \mathrm{c}$ : Points, backed blade fragments and connections between knapped fragments.

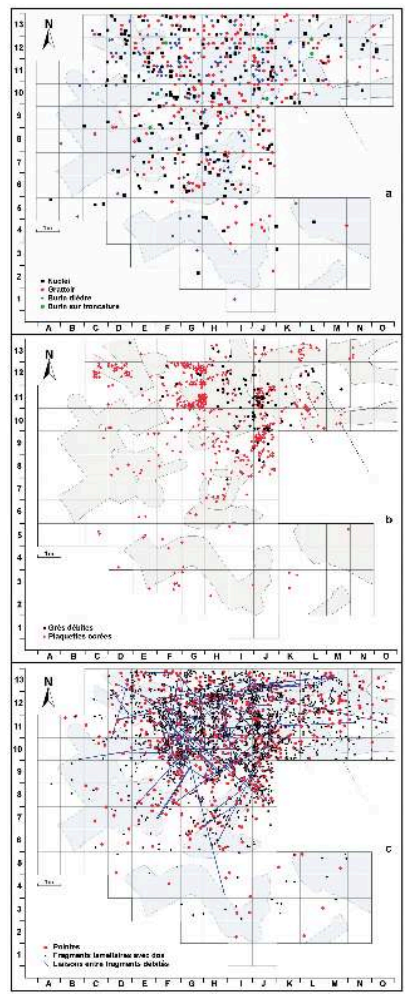

\section{6 - Conclusions concerning the nature and the function of this living space}

112 Although the research results provided information on the type and the role of the camp, many questions persist and will remain unanswered due to the destruction of the excavation.

In spite of the absence of bone material, due to soil acidity, many factors suggest that this was a base camp organized around hunting activities, at the edge of the Narais Plain with abundant game. The many and varied armatures destined for hunting activities were manufactured and maintained at this camp. The presence of two adjustable grooved sandstone plates implies that the shaping of arrow shafts complied with the fine and light format of the armatures found on the site. This suggests a diversification of hunting modes according to the type of game targeted.

The choice of site implantation, the intensive use of hearths the probable presence of two post holes, as well as two zones of leached sand back up the concept of an organized habitat.

The significant concentrations of knapping and retouch waste associated with the combustion areas show that flint knapping was mainly carried out near the hearths. This observation, coupled with the absence of lithic distribution by category and the huge number of knapped products (327,000 knapped flints) also points towards a long occupation of the site by a post-Azilian group and diverse activities linked to hunting. 


\section{BIBLIOGRAPHY}

ALLARD M. 1977 - Rapport de fouilles sur l'habitat nº 1 du Camp d'Auvours à Saint-Mars-LaBrière (Sarthe), SRA Pays de la Loire.

ALLARD M. 1982 - Un habitat de chasseurs au Camp d'Auvours, in J. COMBIER, Les habitats du Paléolithique supérieur, Actes du colloque international, Roanne-Villerest, 1982, Lyon, Direction des Antiquités Préhistoriques Rhône-Alpes, p. 77-79.

ALLARD M., GUYOT R. 1972 - Etude préliminaire d'une industrie magdalénienne au Camp d'Auvours, commune de Saint-Mars-la-Brière (Sarthe), Bulletin de la Société préhistorique française, 69, p. 347-355.

AUBERT G. et BOULAINE J. 1967 - La pédologie, Paris, Presses Universitaires de France, (Que saisje ?), $128 \mathrm{p}$

BAISE D. 2004 - Petit lexique de pédologie, Paris, Institut National de la Recherche Agronomique, $271 \mathrm{p}$.

BARTON R.-N.-E. 1986 - Experiments with Long Blades from Spoughton, near Ipswich, Suffolk, In : D.A. Roe dir., Studies in the Hupper Paeolithic of Britain and Northwest Europe, Oxford, Archaeopress (BAR International Series, 296), p. 129-141.

BORDES F. 1952 - Sur l'usage probable de la peinture corporelle dans certaines tribus moustériennes, Bulletin de la Société préhistorique française, 49, p. 169-170.

DUCHAFFOUR P. 2001 - Introduction à la science du sol, abrégé de pédologie, Paris, Dunod, 6e édition, $331 \mathrm{p}$.

GLORY A. 1961 - Le brûloir de Lascaux, Gallia Préhistoire, 4, 4, p. 174-183.

LEROI-GOURHAN A. 1955 - Les hommes de la préhistoire, les chasseurs, Paris, Bourrelier Coll (La joie de connaître), $128 \mathrm{p}$.

LEROI-GOURHAN A. 1976 - Cours du Collège de France 1976, Paris

L'HELGOUACH J. 1971 - Sarthe, Saint-Mars-la-Brière, Gallia Préhistoire,14, 2, p. 371.

L'HELGOUACH J. 1973 - Sarthe, Saint-Mars-la-Brière, Gallia Préhistoire,16, 2, p. 436-437.

L'HELGOUACH J. 1975 - Sarthe, Saint-Mars-la-Brière, Gallia Préhistoire,18, 2, p. 555-558.

L'HELGOUACH J. 1977 - Sarthe, Saint-Mars-la-Brière, Gallia Prehistoire, 20, 2, p. 442-444

L'HELGOUACH J. 1979 - Sarthe, Saint-Mars-la-Brière, Gallia Prehistoire, 22, 2, p. 577-580.

MARY G. 1964 - Le Périglaciaire des environs du Mans (Sarthe, France), Reprinted from BIULETYN PERYGLACJALNY, nr 13, Łódź, 98 p.

NAUDINOT N. 2008 - Les armatures lithiques tardiglaciaires dans l'Ouest de la France (Région Bretagne et Pays de la Loire) : proposition d'organisation chrono-culturelle et chaîne opératoire de fabrication. In : J.-M. Pétillon, M.-H. Dias-Meirinho, P. Cattelain, M. Honegger, C. Normand, N. Valdeyron (coord.), Recherches sur les armatures de projectiles du paléolithique supérieur au Néolithique (actes du colloque C83, XVe congrès de l'UISPP, Lisbonne, 4-9 septembre 2006), Palethnologie, 1, p. 250-277.

OBERT D. 1988 - Bouloire, carte géologique de la France à 1/50 000, Orléans, Bureau de Recherches Géologiques et Minières, carte à 1/50 000 + livret explicatif, 32 p. + guide de lecture, 21 p. 
POMIES M.-P. 1997 - Pigments rouges préhistoriques : Gothite chauffée ou hématite nanocristalline naturelle, Thèse de doctorat, Paris VI, $248 \mathrm{p}$.

ROZOY J.-G. 1978 - Les derniers chasseurs. L'Epipaléolithique en France et en Belgique. Essai de synthèse, Bulletin de la Société archéologique champenoise, 3 vol.

TRIAT J.-M. 2011 - Les ocres, Paris, Centre National de la Recherche Scientifique, 198 p.

VALENTIN B. 1995 - Les groupes humains et leurs traditions au Tardiglaciaire dans le Bassin parisien. Apports de la technologie lithique comparée, Thèse de doctorat, Paris 1, Paris, 834 p., 200 fig.,117 pl.

\section{ABSTRACTS}

Discovered in 1969, the pre-historical site of the military camp of the plateau of Auvours revealed, near the ground surface, the presence of five sites. The $141 \mathrm{~m} 2$ searched area on site 1 show the remains of an epipalaeolithic camp installed on a pavement of sandstone blocks of periglacial origin. This remains revealed traces of organization including combustion zones and linear accumulations of blocks resulting of re-arrangement of the natural pavement. It seems that part of theses accumulations was used to consolidate the base of the walls made up of perishable materials. When the search was stopped in 1979, a kind of quadrangular shaped enclosure containing three combustion areas was partially excavated. A supplementary combustion zone, kept in reserve for later survey seemed to lie on the external border of this enclosure in a sector having a large proportion of ochre.

The furniture made up exclusively of stone material, having approximately 327000 cut witnesses of which 4200 were altered, was mainly inside the enclosure and also outside in the sector with ochre. All the main layers of stone products are witnesses of a flint cutting activity as well as production and maintenance of tools located near the hearths.

The armatures are mostly represented by points (points of the Blanchères and points with a very slanted truncation) and seem to have thin strips with natural apex described here as "armatures of Auvours". The stigmatas observed on their fractures might be testimonies of the use of bow.

The configuration of the quadrangular area suggest for its protection a single covering comparable with the ones of Thuareg tent. Its North part centralizing miscellaneous material cutting and ochre processing activities constituted a very busy craftsman space which reveals occupations probably associated to hunting. This site, witness mostly of hunting activities, could therefore have been an important camp site for hunters. Its perfect homogeneity rather corresponds to a long and single occupation. Finally, having no reliable dating, it seems preferable in principle to put forward the hypothesis that this vast camp site, with an opening on each side, did not coincide with the cold phase of Dryass III.

Découverte en 1969, la station préhistorique du Camp militaire d'Auvours a révélé, en surface, la présence de cinq sites. La fouille de $141 \mathrm{~m}^{2}$ réalisée sur le site 1 a livré les restes d'un campement épipaléolithique installé sur un pavement de blocs gréseux d'origine périglaciaire. Ces restes ont révélé des traces d'organisation comportant des zones de combustion, des zones ocrées ainsi que des accumulations de blocs résultant de remaniements d'un pavement naturel.

Le mobilier exclusivement lithique composé d'environ 327000 silex débités dont 4200 retouchés était essentiellement contenu dans la moitié nord du site laissant présager d'une prolongation de celui-ci vers le nord. Les principales nappes de mobilier lithique ont toutes témoigné du débitage du silex ainsi que de la fabrication et de l'entretien d'outils à proximité des foyers. Les armatures surtout représentées par des pointes ( $p$. des Blanchères et $p$. à troncature très oblique) semblent aussi comporter des lamelles à apex naturel décrites ici comme «armatures d'Auvours à apex non aménagé ». Les stigmates observés sur leurs fractures pourraient témoigner de l'usage de 
l'arc.

La zone d'installation préhistorique a révélé de multiples activités: aménagement de foyers, débitage du silex, préparation de l'ocre, grattage et tannage des peaux. Ce site, témoin pour l'essentiel d'activités cynégétiques, serait donc un important campement de chasseurs. Sa parfaite homogénéité correspond plutôt à une longue et unique occupation post-Azilienne.

INDEX

Keywords: Epipalaeolithic, camp site of hunters, hunting activitie, combustion area, accumulation of blocs, natural pavement, flat ferruginous granule, point of the Blanchères, armature of Auvours

Mots-clés: Post-Azilien, campement de chasseurs, activité cynégétique, foyer, accumulation de blocs, pavement naturel, plaquette ocrée, pointe des Blanchères, armature d'Auvours à apex aménagé

\section{AUTHOR}

\section{MICHEL ALLARD}

21, rue de Giroussens, FR-31500 Toulouse

michelallard@free.fr 